Revista lus et Praxis, Año 24, № 1, 2018, pp. 497 - 552

ISSN 0717 - 2877

Universidad de Talca - Facultad de Ciencias Jurídicas y Sociales

La inadmisibilidad como forma de invalidez de las actuaciones de parte y de terceros técnicos en el Código de Procedimiento Civil

Jaime Carrasco Poblete

Trabajo recibido el 11 de noviembre de 2016 y aprobado el 28 de marzo de 2017

\title{
La inadmisibilidad como forma de invalidez de las actuaciones de parte y de terceros técnicos en el Código de Procedimiento Civil
}

\author{
THE INADMISSIBILITY AS A FORM OF INVALIDITY OF LEGAL ACTS \\ EMANATING FROM THE PARTIES AND THIRD PARTIES
}

Jaime Carrasco Poblete*

\begin{abstract}
RESUMEN
A través del presente trabajo, se intenta explicar la inadmisibilidad como una forma de invalidez de ciertos actos jurídicos procesales, que emanan de las partes y terceros técnicos. Partiendo de esa base, pretendemos (i) delimitar el concepto, (ii) la oportunidad en que se realiza el juicio o declaración de admisibilidad-inadmisibilidad, (iii) estudiar los efectos que genera esta sanción, (iv) establecer la finalidad que cumple la declaración de inadmisibilidad en el ordenamiento procesal civil, (v) identificar y sistematizar ciertas hipótesis de inadmisibilidad que son transitorias y que permiten la subsanación del defecto y otras que tienen el carácter de permanentes sin posibilidad de subsanación, (vi) identificar y explicar el excesivo rigor formalista con que se interpretan las normas que contienen causales de inadmisión y, finalmente, (vii) demostrar la conexión entre la inadmisión y la eventual infracción del derecho de acceso a la justicia y del derecho al recurso.
\end{abstract}

ABSTRACT

Through this paper we try to explain the inadmissibility as a form of invalidity of certain procedural legal acts emanating from the parties and third parties. On this basis, we intend to (i) delimit the concept, (ii) the timing of the trial or admissibility-inadmissibility statement, (iii) study the effects of this sanction, (iv) Determine the purpose of inadmissibility in the civil procedural legal system, (v) identify and systematize certain assumptions of inadmissibility that are transient and allow for the cure of the defect and others that have the character of permanents without possibility of cure, (vi) identify and explain the excessive rigor formalist interpretation of the rules containing

\footnotetext{
* Abogado, Licenciado en Ciencias Jurídicas (Universidad de los Andes); Doctor en Derecho, Máster en Derecho de la Empresa, Máster en Derecho Público (Universidad de los Andes), Profesor de Derecho Procesal, Facultad de Derecho, Universidad Andrés Bello, Santiago, Chile. Correos electrónicos: jaime. carrasco@unab.cl; jaime.carrasco@endurancelaw.cl. El presente trabajo forma parte del proyecto Fondecyt de iniciación No 11140330: "La inadmisibilidad como forma de invalidez de los actos procesales de las partes y terceros técnicos en el Código de Procedimiento Civil".
} 
grounds for inadmissibility and, finally, (vii) demonstrate the connection between inadmissibility and the possible violation of the right of access to justice and the right to appeal.

\section{Palabras Claves}

Inadmisibilidad, actos procesales, invalidez.

KeY WORDS

Inadmissibility, procedural acts, disability.

\section{Introducción}

El problema en torno al cual se configura esta investigación, consiste en estudiar una de las ineficacias jurídicas que afecta a los actos procesales denominada inadmisibilidad. En otras palabras, lo que se pretende es estudiar la invalidez de los actos jurídicos procesales irregulares que emanan de las partes y terceros en sentido técnico y los diversos problemas tanto teóricos como prácticos, que trae aparejada la inadmisibilidad.

La inadmisibilidad como ineficacia jurídica no ha sido estudiada dogmáticamente por la doctrina ${ }^{1}$, lo que se traduce en existencias de escasas obras que la explican brevemente. No obstante, la inadmisibilidad de un acto concreto, indirectamente, ha despertado cierto interés de parte de la doctrina nacional ${ }^{2}$.

Como se percibe de la bibliografía citada en la nota al pie de página precedente, esta ineficacia jurídica no ha recibido un tratamiento dogmático, sino que solo ha sido analizada indirectamente, razón por la cual merece un estudio particular que explique su naturaleza jurídica, características, requisitos, efectos, utilidad práctica y que sistematice las diversas hipótesis.

Por otra parte, la inadmisibilidad no solo es aplicable en procedimientos de naturaleza civil, sino que se utiliza en la mayoría de los procedimientos (civil, penal, laboral, familia, constitucional, administrativo, policía local, consumo, etc.). En consecuencia, se trata de una forma de invalidez jurídica trascendente cuyo estudio resulta útil para la comunidad jurídica en general.

El estudio de la inadmisibilidad de un acto no ha sido enfocado desde el punto de vista de los actos jurídicos procesales a los cuales le es aplicable, pues, se suele aludir a ella sin distinguir el agente generador del acto procesal (actos del órgano jurisdiccional, partes, terceros, auxiliares de la administración de justicia, etc.).

\footnotetext{
${ }^{1}$ La excepción la constituye ROMero (2017), pp. 49-54.

2 Entre otros, AguirRezÁbal (2014), pp. 81-87; Cortez (2004), pp. 105-139; MASSMANn (2009), pp. 263-293; NúÑez (2012), pp. 15-64; Cañas (2013), pp. 61-78; Hunter (2009), pp. 117-163; Palomo y Valenzuela (2011), pp. 399-415; Mini (2005); Ferrada (2011); Hernández (2002); Mosquera y Maturana (2013), pp. 320 y ss.
} 
Por otra parte, la doctrina no ha estudiado la finalidad que cumple la declaración de inadmisibilidad en el ordenamiento procesal civil, es decir, existe una carencia de estudios sobre las hipótesis de inadmisibilidad y una sistematización de las mismas en relación con los fines que pretende la declaración de inadmisibilidad.

Un problema no resuelto, consiste en que algunas hipótesis de inadmisibilidad son transitorias y permiten la subsanación del defecto o irregularidad (como sucede por ejemplo cuando se inadmite la demanda, art. 256 CPC), en cambio, en otros casos, la declaración de inadmisibilidad es permanente y no se permite la subsanación del defecto procesal (como ocurre por ejemplo con la declaración de inadmisibilidad de los recursos procesales, arts. 201 inc. $1^{\circ}$, 205 inc. $1^{\circ}, 213$ inc. $2^{\circ}, 466$ inc. $3^{\circ}, 778,781$ inc. $2^{\circ}$ CPC). Aquí se percibe, en nuestra opinión, las diferentes funciones que la ley puede asignar a la declaración de inadmisibilidad.

Además de los problemas anteriores, la inadmisibilidad requiere un estudio en relación con la oportunidad en que se realiza el juicio o declaración de admisibilidad-inadmisibilidad y los efectos que genera la aplicación de esta sanción. Estos planteamientos y problemas que brevemente hemos descrito, pretendemos explicarlos a continuación de manera más extensa, con el objeto de manifestar y demostrar que la inadmisibilidad es una ineficacia significativa dentro del ordenamiento jurídico, que tiene constante aplicación y que requiere y merece un estudio dogmático y jurisprudencial, el cual se pretende abordar, en parte, en esta investigación.

\section{La irregularidad o defectuosidad del acto como punto de partida de la invalidez}

El proceso se desarrolla a través de la concatenación de diversos actos procesales dispuestos por la ley, provenientes del órgano jurisdiccional, de los auxiliares de la administración de justicia, de las partes y de terceros ${ }^{3}$. En el ejercicio o desarrollo de los actos procesales se destaca una actividad humana ordenada, que se ajusta a las reglas que dispone el ordenamiento jurídico, a las normas de procedimiento dispuestas por la ley, con el objeto de lograr un fin determinado que no es otro que el proceso sea un instrumento efectivo para el ejercicio de la función jurisdiccional, logrando la solución del conflicto intersubjetivo.

\footnotetext{
${ }^{3}$ En nuestra opinión, una de las más completas clasificaciones sobre los actos procesales CARNeLUTTI, (1944), t. III, pp. 1-604. Más sucintamente, entre otros, CARnelutTI (1973), vol. I, pp. 423-557; GoldsCHMIDT (1936), pp. 227-322; Alsina (1963), t. I, pp. 604-624; SATTA (1971), t. I., pp. 197-245; OrTells (1999), pp. 239-304; Guasp (2002), t. I, pp. 277-316; PAlACIO (1991), t. I, pp. 321-368.
} 
Así, es destacable que por una parte existe una voluntad humana que está preordenada por la ley pues, es el ordenamiento positivo el que dispone reglas de conducta, principios informativos o reglas técnicas, orden de ejecución de los actos, todos los cuales forman el proceso. Por otra parte, el proceso se desenvuelve de acuerdo a un orden consecutivo legal, regulando la conducta humana manifestada en la actividad procesal de diversos sujetos, actos procesales que deben desarrollarse conforme con lo dispuesto por la ley, la que finalmente atribuye efectos a esas manifestaciones de voluntad incorporadas al proceso.

Atendido esto, se percibe que el fenómeno de la invalidez, dentro de la cual está inserta inadmisibilidad, parte de la base que la conducta de los sujetos que intervienen en el desarrollo o comisión de los actos procesales que forman el proceso, pueden presentar ciertos desajustes con el modelo normativo, generándose una irregularidad o desviación jurídica, lo que constituye que el acto pueda conceptualizarse como irregular, defectuoso o viciado.

Sin embargo, en nuestra opinión, dependiendo del origen del acto procesal, la irregularidad del mismo no tiene o no debe tener el mismo tratamiento procesal en cuanto a la validez-invalidez. Así, por una parte, deben diferenciarse los actos que tienen su origen en el órgano jurisdiccional y los auxiliares de la administración de justicia y, por otra, aquellos actos que emanan de las partes y terceros en sentido técnico. En virtud de esta distinción-que es esencial y que prácticamente pasa inadvertida por la doctrina y jurisprudencia- consideramos que el tratamiento procesal que la ley asigna a los defectos de los actos procesales que emanan de las partes no es la misma que la que se atribuye a las irregularidades de los actos procesales que emanan del órgano jurisdiccional.

\section{El distinto tratamiento de las irregularidades procesales atendiendo al origen de los actos procesales}

Las irregularidades que padecen los actos procesales que tienen su origen en las partes y terceros en sentido técnico, difieren del tratamiento procesal que se asigna a los defectos que adolezcan los actos del órgano jurisdiccional y de los auxiliares de la administración de justicia.

Las diferencias se aprecian al analizar el ordenamiento jurídico, el cual dispone comúnmente la sanción de nulidad contra ciertos actos defectuosos que provienen del órgano jurisdiccional o de ciertos terceros metajurídicos; en cambio, asigna ordinariamente la sanción de inadmisibilidad contra ciertos actos irregulares que tienen su origen en las partes o terceros en sentido técnico.

Esta diferencia se aprecia más nítidamente cuando se responde a la pregunta ¿qué es lo que se quiere anular y qué actos puedes ser declarados inadmisibles? 
En efecto, en el proceso civil, durante el transcurso del proceso, lo que se pretende anular es, por lo general, el emplazamiento aparente que sufrió el demandado, o una determinada resolución judicial que adolezca de un vicio o defecto trascendente, o una prueba que se practicó sin la observancia de la ley y que causa perjuicio a alguna de las partes. Posteriormente, al finalizar cada grado jurisdiccional, se abre paso a las partes para que impetren los medios de impugnación, dentro de los cuales nuestro sistema contempla, entre otros, la apelación, la casación en la forma y fondo y la revisión, a través de los cuales, de una u otra manera, se puede lograr la invalidación de la sentencia y de los actos de procedimiento que han sido desarrollados sin observar la legalidad, cumpliéndose los demás requisitos necesarios para que prospere la sanción procesal de que se trate.

Normativamente, las causales específicas de nulidad procesal están dispuestas, por lo general, a propósito de los incidentes especiales de nulidad por fuerza mayor (art. $79 \mathrm{CPC}$ ), por falta de emplazamiento (art. $80 \mathrm{CPC}$ ), y en las causales del recurso de casación en la forma (art. 768 CPC), sin perjuicio de la causal genérica de nulidad contemplada en el artículo 83 del CPC y de la posibilidad que el juez de oficio declare la misma cuando se cumplen los requisitos del artículo 84 del mismo Código.

En cambio, cuando un acto que emana de las partes o de terceros en sentido técnico, incumple una exigencia o requisito que dispone el ordenamiento jurídico, este no lo trata como acto nulo sino que le asigna otro tipo de invalidez como, entre otras, por ejemplo, la inadmisibilidad (arts. 201 inc. $1^{\circ}, 205$ inc. $1^{\circ}, 213$ inc. $2^{\circ}, 466$ inc. $3^{\circ}, 778,781$ inc. $2^{\circ}$ ), la preclusión, decadencia o consumación del acto (art. 64 inc. $1^{\circ} \mathrm{CPC}$ ), la deserción del recurso ${ }^{4}$ (art. 201 inc. $2^{\circ}, 779 \mathrm{CPC}$ ) o el desistimiento del mismo (art. 197 inc. $\left.3^{\circ} \mathrm{CPC}\right)$.

Lo que hemos tratado de manifestar, es que la sanción de invalidez que recae sobre los actos defectuosos que tienen su origen en el órgano jurisdiccional o en terceros vulgares es la nulidad, en cambio, la especie de invalidez que se asigna a los actos irregulares que emanan de las partes o terceros en sentido técnico suele ser la inadmisibilidad, sin perjuicio de otras sanciones que el ordenamiento establece para determinadas hipótesis.

\footnotetext{
${ }^{4}$ Hacemos presente que la institución de la deserción del recurso, producto de la modificación introducida al Código de Procedimiento Civil por la Ley № 20.886, en la actualidad se encuentra derogada toda vez que fueron modificados los artículos 197 y 201 del referido Código. Sin embargo, todavía es útil citar este ejemplo porque en virtud del artículo $2^{\circ}$ transitorio de la Ley $N^{\circ} 20.886$, esta no se aplica a las causas iniciadas con anterioridad a su entrada en vigencia, por lo que en la actualidad existen miles de recursos de apelación y casación en que pueden ser declarados desiertos.
} 
En virtud de lo anterior, pasaremos a analizar la invalidez de los actos del órgano jurisdiccional para luego referirnos a los actos que tienen su origen en las partes y terceros en sentido técnico.

\subsection{Los actos que emanan del órgano jurisdiccional}

Hemos afirmado que, dependiendo del origen del acto, varía el tratamiento procesal en cuanto a su eficacia. En efecto, la dialéctica del proceso civil implica que, para que este se desarrolle y avance, es necesario que tanto las partes como el órgano jurisdiccional desarrollen actos jurídicos procesales de manera concatenada, en el orden consecutivo legal que indica el procedimiento regulado por la ley (art. $63 \mathrm{~N}^{\circ} 3 \mathrm{CPR}$ ).

En esta diversidad de actos procesales se aprecia que la eficacia de aquellos que tienen su origen en las partes y terceros técnicos es heterogénea, respecto de la eficacia de los actos que emanan del órgano jurisdiccional o de los auxiliares de la administración de justicia. En este apartado nos referiremos especialmente a estos últimos, reservando el análisis del resto de los actos para el apartado siguiente.

Los actos del órgano jurisdiccional y de sus auxiliares o terceros metajurídicos son una especie de actos procesales.

Los actos del juez son diversos, siendo los más importantes o destacados las resoluciones judiciales (art. $158 \mathrm{CPC}$ ), porque en estas se manifiesta la potestad jurisdiccional, la voluntad de la ley, a través de aquellas avanza el procedimiento $y$, finalmente, se resuelve la controversia de relevancia jurídica.

Las resoluciones judiciales tienen un especial tratamiento en el Código de Procedimiento Civil, el cual destina para su regulación el Título XVII del Libro I, denominado De las resoluciones judiciales. La normativa pertinente se encarga, entre otras cosas, de clasificarlas y determinar su objeto (art. 158 CPC), de regularlas en forma general (arts. 61 y 169 CPC), de manera particular (arts. $170,171, \mathrm{AA}$. sobre la forma de las sentencias de 1920) y de los efectos que producen (arts. 175, 177, 178, 179, 180, $182 \mathrm{CPC})^{5}$.

Dentro de los actos del órgano jurisdiccional se incluyen los actos del secretario judicial ${ }^{6}$ (arts. 379-389 COT) y de los terceros vulgares o ajenos al juicio (receptores, peritos, testigos, relatores, etc.), también denominados como agentes de la jurisdicción o auxiliares de la administración de justicia (título IX del COT, arts. 350-457 bis).

${ }^{5}$ Stoehrel (2009), pp. 95-142.

${ }^{6}$ Colombo (1997), t. II, p. 353. 
Las resoluciones judiciales solo producirán efecto en virtud de notificación hecha con arreglo a la ley, salvo los casos expresamente exceptuados ${ }^{7}$ por ella (art. $38 \mathrm{CPC}$ ). Se entiende que una resolución judicial es notificada con arreglo a la ley cuando ha sido comunicada a las partes a través de alguna forma de notificación que indica la ley ${ }^{8}$. La mayoría de las resoluciones judiciales, una vez notificadas, desplegarán sus efectos, sin más trámite. En otras palabras, las resoluciones judiciales, en general, no están sometidas a ningún tipo de control previo o inicial (ex ante) que tenga por objeto manifestar alguna irregularidad o ilegalidad que pueda padecer, tanto desde el punto de vista formal como en su aspecto o contenido de fondo.

Las resoluciones judiciales solo podrán ser controladas en su aspecto formal y de fondo a través de los medios de impugnación que dispone la ley, en cuanto fueren procedentes, dependiendo de la naturaleza jurídica de la resolución que se pretende atacar. Este control de legalidad, en virtud del principio dispositivo, deben ejercerlo por regla general las partes pues, una vez que la resolución se notificó a alguna de estas, el juez está impedido de alterarla en virtud del desasimiento del tribunal, que deja a salvo la posibilidad de aclarar los puntos obscuros o dudosos, salvar los errores de copia, de referencia o de cálculos numéricos, que aparezcan de manifiesto en la misma sentencia (art. 182 CPC). Tal atribución la podrá ejercer el juez, a petición de parte o de oficio (art. 184 CPC).

En virtud de lo expuesto, afirmamos que el régimen de validez del acto que tiene su origen en las partes o terceros técnicos es distinto que el sistema de validez de los actos que provienen del órgano jurisdiccional o de terceros vulgares. En efecto, el hecho de incorporar materialmente un acto de parte al proceso, no implica inmediatamente su eficacia pues, eso dependerá que el acto resulte admitido; los actos del órgano jurisdiccional, en cambio, producen sus efectos

\footnotetext{
${ }^{7}$ Entre estos casos se pueden mencionar los siguientes, a saber: a) aquella resolución que acoge una medida prejudicial precautoria o precautoria propiamente tal, cuando el demandante solicitó que la medida se decrete sin previa audiencia del demandado (inaudita parte), siempre que existan razones graves para ello y el tribunal así lo ordene (art. 302 inc. $2^{\circ} \mathrm{CPC}$ ); b) la resolución que acoge la demanda posesoria de obra nueva, en la parte que ordena la suspensión de la ejecución de la obra, no necesita ser notificada al demandado para que produzca efectos, bastando para que se produzca esta suspensión que se le notifique a quien esté dirigiendo o ejecutando la obra (art. 566 CPC); c) en caso que el apelado sea rebelde en comparecer ante el tribunal de alzada a seguir el recurso de apelación, se seguirá el recurso en su rebeldía por el solo ministerio de la ley y no será necesario notificarle las resoluciones que se dicten, las que producirán sus efectos respecto del apelado rebelde desde que se pronuncien (art. 202 inc. $1^{\circ} \mathrm{CPC}$, actualmente derogado por la Ley $\mathrm{N}^{\circ} 20.886$, pero aún aplicable a todas aquellas causas a las cuales no se les aplica la referida Ley). Una explicación sobre estas hipótesis en CAmiRUAGA (2004), pp. 34-55. Respecto a la rebeldía del apelante y del apelado CARRASCO (2010), pp. 100-102.

${ }^{8}$ Sobre esta regla general de notificación y en el sentido que exponemos CAmiruagA (2004), pp. 32 y ss.
} 
desde que se notifican válidamente y en forma inmediata, con independencia de si se ajustaron al modelo legal. Incluso, en caso que las partes impugnen un determinado acto -especialmente a través de un recurso-, los efectos de este se mantienen en el tiempo, al menos hasta que se revoque o invalide la resolución por el tribunal superior.

Esta distinción -dice con razón Hernández Galilea- "debe ser tenida en cuenta a la hora de analizar las peculiaridades de la nulidad en el proceso, pues siendo la nulidad una categoría cuya finalidad es la eliminación de los efectos, debe aplicarse solamente a los actos jurídicos que puedan producirlos. En consecuencia, debemos concluir que en el ámbito procesal, en sentido estricto, sólo los actos jurisdiccionales son susceptibles de ser considerados nulos ${ }^{\prime \prime}$.

Esta diferencia no ha sido propuesta por la doctrina procesal de nuestro país ${ }^{10}$, sí por la comparada ${ }^{11}$; divergencia que consideramos correcta y plenamente aplicable a nuestro sistema procesal civil.

Es más, del análisis del sistema anulatorio puede concluirse que la invalidez regulada en los recursos de casación en la forma (art. 766 CPC), en el fondo (art. 767 CPC) y revisión (art. 810 CPC) tiene por objeto atacar una resolución judicial, cuya naturaleza, dependiendo del caso concreto, será una sentencia interlocutoria o definitiva con las particularidades que cada norma indica. Lo mismo ocurre con la nulidad por fuerza mayor (art. 79 CPC) y por falta de emplazamiento (art. 80 CPC) pues, en ambas hipótesis, lo que se pretende dejar sin efecto son los efectos de los actos jurídicos procesales realizados por la parte contraria, los cuales han sido incorporados al proceso a través de diversas resoluciones judiciales. En otras palabras, esos actos que emanan de

\footnotetext{
${ }^{9}$ HeRnándeZ (1995), p. 106.

${ }^{10}$ Nuestra doctrina aplica la nulidad procesal a toda la actividad procesal sin distinguir el origen del acto. En este sentido, entre otros, SALAS (2004), p. 82, al afirmar que la nulidad procesal es aplicable a todos los actos del proceso. El autor señala que: "Se ha dicho que la nulidad estudiada es una sanción de ineficacia procesal, pero, no obstante tal carácter, su acción es amplísima, puesto que afectará de una manera genérica a todos los actos del proceso ejecutados imperfectamente, sin necesidad de que el legislador la prescriba para cada caso particular" (la cursiva es nuestra). También hace aplicable la nulidad tanto a los actos del juez como de las partes y terceros, Colombo (1997), t. II, p. 433, al afirmar que: "si el juez o las partes desajustan el proceso al procedimiento incurren en un vicio que autoriza la invalidación de actos procesales individuales o de todo el proceso según corresponda, restableciéndose así la igualdad. Lo mismo ocurrirá si es violentada por el sentenciador la ley decisoria litis". Más claramente lo señala en la pág. 469, al disponer que: "la nulidad puede afectar a los actos del tribunal, de las partes y de los terceros que pueden actuar en el juicio" (la cursiva es nuestra). Además, el autor en varias partes de su obra hace aplicable la nulidad a todos los actos procesales, sin distinción alguna.

${ }^{11}$ Hacen esta distinción en el derecho español, entre otros, HeRnández (1995), pp. 105 y ss.; AndRés (2005), pp. 135 y ss. En el derecho argentino Creus (1995), pp. 116 y ss.; Otranto et al (2005), p. 424; Palacio (1972), pp. 146-147; Clariá (1983), t. II, p. 119.
} 
la contraparte han producido efectos porque han sido admitidos al proceso en virtud de diversas resoluciones judiciales, razón por la cual el articulista atacará, a través de un incidente, las resoluciones judiciales que se dictaron durante todo el período de tiempo en el cual estuvo impedido de comparecer debido a la fuerza mayor, o todas aquellas resoluciones que se dictaron durante el transcurso del juicio en virtud de un emplazamiento inválido o aparente o la actuación misma del ministro de fe que practicó el emplazamiento irregular. Lo anterior, ratifica nuestra proposición que la nulidad procesal solo tiene por objeto los actos que provienen del órgano jurisdiccional o las actuaciones judiciales de los agentes de la jurisdicción ${ }^{12}$.

Nuestra afirmación también se apoya al acudir al elemento práctico, a la realidad del proceso. Resulta ilógico pretender anular un acto de parte, pues, si este aún no ha sido admitido al proceso, entonces no ha producido ningún efecto, por lo que nada hay que anular. Una vez que el acto de parte es declarado expresa o implícitamente admisible, ahí será posible atacarlo, pero nótese que la nulidad se implorará contra la resolución que, de una u otra forma admitió el acto de parte, que accedió a la petición invocada, la cual contiene un determinado vicio susceptible de anularse ${ }^{13}$, o contra el acto inválido realizado por un auxiliar de la administración de justicia, siempre que padezca de una irregularidad invalidante y que se cumplan los demás requisitos legales para que prospere la declaración de nulidad.

Así, por ejemplo, un litigante impetrará un incidente de nulidad con el objeto de eliminar los efectos del emplazamiento aparente; para anular una prueba rendida fuera de plazo en la cual no tuvo posibilidad de defenderse; para invalidar una resolución del proceso que no respetó el derecho a la bilateralidad de la audiencia. Posteriormente, se podrá invalidar una sentencia dictada por un tribunal incompetente; por contener decisiones contradictorias; por haberse fundado en pruebas declaradas falsas en un juicio posterior; por no haberse respetado la imparcialidad del juzgador. Finalmente, también se podrá invalidar una sentencia por razones de fondo, cuando no se aplique correctamente la ley, cuando haya una errónea interpretación de la ley, una falsa aplicación de la ley y en general, cuando exista una infracción de ley que influya sustancialmente en lo dispositivo de la sentencia.

\footnotetext{
${ }^{12}$ El problema puede originarse en virtud del tenor literal del incidente de nulidad general (art. 83 CPC), que no distingue el origen del vicio, lo que puede dar lugar a sostener, a nuestro entender equivocadamente, que la nulidad se aplica indiscriminadamente a cualquier actividad procesal, independiente de su origen. Sin embargo, lo anterior es solo una interpretación, pues, la norma tampoco señala que se aplica a todos los actos procesales.

${ }^{13}$ Gimeno (1949), p. 513.
} 
En virtud de lo anterior, es manifiesto que lo invalidable a través de la nulidad procesal son las resoluciones judiciales y las actuaciones judiciales de los agentes de la jurisdicción.

En consecuencia, las distinciones pretéritas permiten comprender coherentemente la articulación del sistema anulatorio en el proceso civil, el cual tiene por objeto eliminar los efectos de los actos que emanan del órgano jurisdiccional o de los agentes de la jurisdicción, siempre que se cumplan los requisitos para su procedencia, reservando para los demás actos otra sanción distinta, la denominada inadmisibilidad, la cual explicaremos a continuación.

\subsection{Los actos que tienen su origen en las partes}

Nuestros Códigos de Procedimiento no regulan sistemáticamente la inadmisibilidad de los actos procesales.

El ordenamiento jurídico procesal utiliza la acepción inadmisibilidad, en general, para imponer una sanción a los actos que provienen de las partes cuando éstos incumplen alguno de los requisitos que la ley dispone ${ }^{14}$. También puede entenderse que la regulación aislada de la inadmisibilidad genera una amenaza para los actos de las partes cuando éstos incumplen ciertos requisitos que la ley considera necesarios para la validez y eficacia del acto.

La utilización de este término es amplia, pues, no tiene una delimitación clara en nuestro ordenamiento, asignándole variadas funciones que conviene puntualizar para distinguir la inadmisibilidad de la nulidad procesal.

Los actos procesales de parte y de terceros en sentido técnico, para que sean incorporados al proceso, requieren de un examen o control de regularidad o legalidad ex ante que los diferencia de los actos que emanan del órgano jurisdiccional y de sus auxiliares, los cuales producen efectos desde que se notifican a las partes en la forma prevista en la ley. Este control de regularidad que afecta los actos de parte es insoslayable para determinar la validez y eficacia que puede generar un acto procesal.

\footnotetext{
${ }^{14}$ Quezada (1984), p. 145; Molina (2007), pp. 23 y 24. Clariá (1983), t. II, p. 118, afirma que: "la inadmisibilidad es la sanción de naturaleza procesal mediante cuya aplicación se impide ab initio que produzcan efecto en el proceso los actos de parte (o de algunos terceros en actos no requeridos por el tribunal), por habérselos realizado sin observar determinados requisitos de forma o careciendo de la facultad para actuar válidamente". De LA RúA (1991), p. 81, partiendo de la misma definición de Clariá sostiene que "este concepto amplio y descriptivo comprende dos aspectos: el defecto en la forma exterior (criterio objetivo) y el defecto en el poder para cumplir la actividad (criterio subjetivo). El defecto en la forma consiste en una deficiencia estructural del acto, por no adecuarse al esquema legal regulado imperativamente. El defecto en el poder consiste en la ausencia de la atribución para desplegar la actividad que se pretende cumplir, sea por haberse extinguido la posibilidad de actuar, no obstante el poder que se tuvo para hacerlo (impugnación vencido el término), o por haberse agotado por su ejercicio anterior".
} 
Las actuaciones que provienen de las partes no producen efectos en forma directa o inmediata, sino que están subordinados a un control preventivo de regularidad o admisibilidad. En efecto, si el acto que emana de la parte cumple los requisitos que dispone el ordenamiento jurídico, el juez dictará una resolución por la cual lo admitirá explícita o implícitamente, originándose las consecuencias o efectos que dispone la ley en cada hipótesis particular. Por el contrario, la inobservancia de alguna exigencia legal o su improcedencia de acuerdo al orden consecutivo legal, impedirá que el juez lo admita, con lo cual, en virtud de esa valoración negativa, el acto no producirá efecto alguno, o más precisamente, no alcanzará a producir efectos jurídicos.

En consecuencia, la admisión o inadmisión de un acto procesal solo es aplicable a aquellos actos procesales que emanan de las partes o de terceros en sentido técnico.

\section{Diversas interpretaciones de la voz admisión}

La ley procesal no define lo que debe entenderse por admisión, admisibilidad, inadmisibilidad. La ley simplemente utiliza en diversas disposiciones los términos "admitirá" (arts. 22, 117, 207, 237, 310, 355, 373, 378, 433, 493, 497, 713, 769 y 909 CPC), "admisibilidad/inadmisibilidad" (arts. 466 y 781 CPC) y "admisión" (art. 697 CPC).

El Diccionario de la Lengua Española de la Real Academia Española contiene dos acepciones para la palabra "admisión": "1. f. Acción y efecto de admitir. 2. f. Der. Trámite en que, atendiendo a aspectos formales, se decide si una demanda, recurso o petición deben ser tomados en consideración para resolver el fondo". Admitir se define como "aceptar, permitir". Admisibilidad significa, según el mencionado diccionario, como "cualidad de admisible". En similar sentido la explica Couture al definirla como "acción y efecto de dar entrada, normalmente por parte del juez, a una defensa, petición o documento, en razón de su procedencia formal o sustancial"15.

En nuestra doctrina cabe destacar a Gorigoitía Abbott, quien la define como una "... técnica de control de los actos de parte que, entre otros objetivos, tiene el de controlar in limine su validez, impidiendo la incorporación al proceso de actos defectuosos"16, a Romero Seguel, que la define como "la sanción que se aplica por sentencia judicial al acto procesal realizado, sin observar las exigencias formales o de fondo que lo hacen procedente"17, y a Quezada Meléndez,

${ }^{15}$ Couture (2013), p. 82.

${ }^{16}$ Gorigoitía (2013), p. 146.

17 Romero (2017), p. 49 
quien explica que la inadmisibilidad "suele definirse como una especie de ineficacia jurídica que actúa antes que el acto se consume o produzca efectos y que se traduce en el rechazo temporal o definitivo del mismo en virtud del quebrantamiento de un requisito de forma del acto procesal" ${ }^{18}$

Por un lado, puede atribuirse a la inadmisibilidad el significado de "procedente". En efecto, diversos son los preceptos legales que utilizan el vocablo admitir o admisión en este sentido. Así, a modo de ejemplo y sin agotar los múltiples ejemplos que podrían citarse, el artículo 22 se refiere a admitir la intervención de tercero principal o excluyente, el artículo 117 a la admisión de las implicancias y recusaciones contra los funcionarios subalternos, el artículo 207 a la admisión de la prueba en segunda instancia, el artículo 237 a que no se admitirán excepciones que hayan podido oponerse en el juicio anterior, el artículo 310 a que la admisión de las excepciones perentorias anómalas debe formularse por escrito y en la oportunidad que ahí se indica, el artículo 355 a la admisión de medios probatorios en el incidente sobre autenticidad de un instrumento, el artículo 373 a que solo son admisibles como tacha las que expresan los artículos 357 y 358, el artículo 378 que no admite prueba de testigos para inhabilitar los que hayan declarado sobre las tachas deducidas, el artículo 433 a que citadas las partes a oír sentencia no se admitirán escritos ni pruebas de ningún género, el artículo 493 relativo a que no se admitirá postura que baje de los dos tercios de la tasación, el artículo 497 en cuanto a que para inscribir la propiedad adjudicada en remate el Conservador de Bienes Raíces no admitirá sino la escritura definitiva de compraventa, el artículo 713 referente a la reconvención en el procedimiento de mínima cuantía y el artículo 909 relativa a la admisión de la información de testigos. En todas estas hipótesis, la ley de refiere al vocablo admitir o admisión (o en su caso en forma negativa: no se admitirá) como sinónimo de procedencia, dar entrada, recibir o aceptar una intervención, excepción, prueba, incidente, etc.

Distinta es la cuestión en otros preceptos que tratan la admisión como un control que ejerce el tribunal de ciertos requisitos que exige la ley, para que el acto procesal de parte produzca efectos jurídicos. Así ocurre con los exámenes de admisibilidad-inadmisibilidad, a propósito de la demanda cuando esta no cumple con los requisitos formales para que sea admitida a tramitación (art. 254 CPC), con los requisitos que deben cumplir el ejecutado para oponer excepciones en un juicio ejecutivo (arts. 465 y 466 CPC ) o con los requisitos que deben cumplir diversos medios de impugnación como por ejemplo el recurso de apelación (arts. 189, 200, 201 CPC), casación forma y fondo (arts. 769, 772, 776, 778, 781, 782 CPC) para que sean declarados admisibles. En estas últimas

${ }^{18}$ Quezada (1984), p. 145. En similar sentido Molina (2007), pp. 23 y 24. 
hipótesis, la inadmisibilidad constituye una forma de invalidez por faltar al acto de parte los requisitos formales dispuestos por la ley para que este produzca efectos jurídicos.

Del estudio y análisis de los preceptos legales que aluden a la admisión, resulta posible afirmar que en ciertos casos se ocupa el vocablo para significar la procedencia de un acto procesal, en otros como un juicio sobre el cumplimiento de ciertos requisitos formales de un acto procesal $y$, finalmente, como un examen previo vinculado al fondo del asunto controvertido.

Como se ha desarrollado brevemente en las hipótesis anteriores, la inadmisibilidad significa que un acto procesal de parte o de un tercero técnico es aceptado dentro del procedimiento, como también puede referirse al cumplimiento de ciertos requisitos o exigencias legales para que esos actos produzcan efectos jurídicos. Cuando a dichos requisitos o exigencias legales se les asigna una naturaleza meramente formal, pareciera que no se producen mayores inconvenientes sobre el punto -salvo que tales exigencias se interpreten de manera ritualista o formalista-, pero el problema es distinto cuando la inadmisión se vincula a un examen o juicio sobre el fondo del asunto controvertido o de un determinado acto procesal. Dentro de estas hipótesis aparecen las causales de inadmisión de la demanda o de una acción o recurso por manifiesta falta de fundamentos, hipótesis que trataremos más adelante.

\section{La forma clásica de explicar la inadmisibilidad: imposibilidad de entrar a conocer el fondo del asunto por falta de presupuestos procesales}

Desde una perspectiva clásica, la inadmisión se comprendía como una imposibilidad del tribunal de entregar una respuesta sobre el fondo del asunto controvertido por faltar los denominados presupuestos procesales ${ }^{19}$.

El concepto de presupuestos procesales no está presente en nuestra legislación, siendo la doctrina la encargada de desarrollarlo ${ }^{20}$. Esta denominación es fruto de la clásica obra del jurista alemán Von Bülow ${ }^{21}$ y su concepto ha evolucionado con el desarrollo de nuestra disciplina ${ }^{22}$. Para nosotros, los presu-

\footnotetext{
${ }^{19}$ Así lo explica Cierco (2009), pp. 35 y ss.

${ }^{20}$ El concepto, clasificación y desarrollo de los presupuestos procesales han sido desarrollados especialmente en nuestra doctrina por ROMERo (2007), t. I., pp. 26-28.

${ }^{21}$ VON BüLOW (2008).

${ }^{22}$ Los presupuestos procesales, en la concepción de Von Bülow (2008), pp. 26 y ss., eran considerados como presupuestos o elementos de existencia del proceso visión que fue criticada por gran parte de la doctrina, pues, el proceso existía independientemente de si se cumplen o no los presupuestos procesales. De ahí que Goldschmidt, (1936), p. 19, objete la noción de presupuestos procesales propuesta por Von Bülow y sostenga que: "Ios presupuestos procesales no representan presupuestos
} 
puestos procesales constituyen "... aquellas circunstancias formales, establecidas por la ley procesal, que deben concurrir en el proceso para que sea posible la resolución sobre el fondo del asunto sometido a la consideración judicial, las cuales deben, además, observarse de oficio" ${ }^{\prime 23}$.

De esta orientación moderna de los presupuestos procesales se pueden extraer dos consecuencias: la primera, que los presupuestos procesales son ciertas formalidades, es decir, son requisitos de validez del proceso; y la segunda, que los presupuestos procesales son necesarios para que el juez pueda pronunciarse sobre el objeto del proceso, es decir, sobre el fondo del asunto ${ }^{24}$.

Desde este punto de vista, la inadmisibilidad tiene dos características, a saber, por un lado, se trata de un acto de terminación del proceso y, por otro, cuando el juez declara inadmisible la pretensión no resuelve el fondo del asunto. En este sentido debe distinguirse el juicio de admisión-inadmisión del juicio de estimación-desestimación de la pretensión.

En efecto, desde esta perspectiva clásica, en el primero, la demanda no se acepta o admite a tramitación por faltar los denominados presupuestos procesales, dictándose una sentencia procesal o absolutoria en la instancia, dejando imprejuzgada la pretensión y, por lo mismo, esa resolución judicial no produce efecto de cosa juzgada material.

En cambio, cuando la demanda es estimada o desestimada el tribunal resuelve el fondo del asunto, la controversia formulada por las partes, abordando el thema decidendum, pronunciándose una sentencia sustancial con efecto de cosa juzgada material.

del proceso, sino de una decisión sobre el fondo" y la falta de uno de estos implica que se dicte una sentencia absolutoria en la instancia. En similar sentido CHIOvendA (1954), t. I., pp. 77 y ss. y t. III, pp. 33 y ss.; Fairén (1990), p. 335; Fernández (1992), t. II, pp. 49 y ss. Posteriormente, el concepto es desarrollado en Latinoamérica por COUTURE, (2011), pp. 85-90, quien distingue entre presupuestos procesales de la acción, de la pretensión, presupuestos de validez del proceso y presupuestos de una sentencia favorable. Sobre el concepto de presupuestos procesales, su evolución y críticas. MARINONI et al (2010), pp. 416 y ss.

${ }^{23}$ Romero (2007) t. I., p. 27. En sentido similar López (1991), pp. 44 y ss.; Hernández (1995), p. 91.

${ }^{24}$ Muy ilustrativa es la explicación de Calamandres (1996), vol. I, p. 348, quien sostiene que: "para vencer una causa, no basta tener razón sobre el mérito; sino que es necesario también hacerla valer en los modos prescritos por el derecho procesal, a falta de lo cual el órgano judicial no podrá entrar a conocer si el reclamante tiene razón o no la tiene, y no podrá, por consiguiente, dictar la providencia jurisdiccional de mérito, a la cual el reclamante aspira; de modo que la providencia consistirá simplemente en declarar no proveer...". Luego, el mismo autor, concluye diciendo que "... los presupuestos procesales son las condiciones que deben existir a fin de que pueda tenerse un pronunciamiento cualquiera, favorable o desfavorable, sobre la demanda, esto es, a fin de que se concrete el poder-deber del juez de proveer sobre el mérito (...), los presupuestos procesales son requisitos atinentes a la constitución y al desarrollo de la relación procesal, independientemente del fundamento sustancial de la demanda" (vol. l, p. 351). 


\section{Las características de la inadmisibilidad}

Como hemos expresado, la declaración de inadmisión de un determinado acto procesal impide, ab initio, que este despliegue o genere los efectos dispuestos por la ley.

En este sentido, la inadmisibilidad constituye una sanción de invalidez que consiste en un juicio de calificación de regularidad o validez inicial de los actos que tienen su origen en las partes o terceros técnicos que, en caso de actuar, obstará a que se generen los efectos propios del acto.

De esta definición se pueden extraer varias conclusiones, algunas de las cuales ya se han expuesto preliminarmente, pero que corresponde analizar más detalladamente, a saber:

\subsection{La inadmisión constituye un juicio o calificación de regularidad de los actos de las partes o de terceros en sentido técnico}

Sostenemos que el juicio de inadmisibilidad solo puede referirse a los actos de las partes y de terceros en sentido técnico ${ }^{25}$, porque esos actos son los que deben ser calificados por el juez como admisibles o inadmisibles, calificación que dependerá del cumplimiento más o menos estricto de los requisitos que dispone la ley. Realizada esta calificación y verificado el cumplimiento de los requisitos del acto, se declarará expresa o implícitamente su admisibilidad, generándose todos los efectos propios del mismo.

En efecto, los actos de parte, para que produzcan los efectos legales, necesitan de una valoración que los admita al proceso. Esa calificación de admisión-inadmisión es más o menos rigurosa, pero existe siempre y se referirá, por lo general, a la correspondencia del acto de acuerdo al orden consecutivo legal, que emane de alguna de las partes del juicio o de su representante, que se evacúe dentro de la oportunidad que corresponda y que sea redactado en forma respetuosa.

Ciertos actos procesales están sometidos a un juicio o calificación de admisibilidad más riguroso, como ocurre, por ejemplo, con los requisitos que deben cumplirse para interponer un recurso de apelación, casación en la forma y casación en el fondo. Esta mayor o menor rigurosidad en la verificación de los requisitos y formalidades de ciertos actos obedece a los fundamentos que se asignan a la inadmisibilidad en nuestro sistema procesal, los cuales hay que estudiarlos caso a caso.

Por lo dicho, negamos que esta forma de invalidez sea aplicable a los actos que provienen del órgano jurisdiccional o de alguno de los auxiliares de la

${ }^{25}$ Así lo explican Gorigoitía (2013), p. 146; Hernández (1995), p. 204; Andrés (2005), p. 135; Yélamos (2006), p. 74. 
administración de justicia pues, la casuística del proceso impide apreciar de inadmisible un acto procesal emanado del juez o de algún tercero metajurídico. Estos actos no necesitan de un juicio o calificación jurídica de admisibilidad, sino que, una vez dictados y notificados válidamente (art. 38 CPC) o ejecutados y luego de dejar testimonio de ellos en los autos, producirán sus efectos, abriéndose la posibilidad de impugnarlos a través de los múltiples mecanismos procesales que dispone el ordenamiento jurídico.

La irregularidad, defectuosidad, ilegalidad o antijuridicidad de las resoluciones judiciales o de los actos de terceros metajurídicos, serán controladas a petición de parte o de oficio, a través de los disímiles medios de impugnación que dispone el ordenamiento jurídico.

\subsection{La inadmisibilidad es predicable respecto de todos los actos de postulación y de causación que emanen de las partes y de terceros en sentido técnico}

Afirmamos que todos los actos de las partes y de terceros en sentido técnico son calificables de admisibles e inadmisibles. Para determinar esto, es necesario clasificar los actos procesales de parte, lo cual constituye una difícil tarea, pues, cada comentarista realiza diversas clasificaciones utilizando disímiles criterios.

Por esta razón, explicaremos los actos de las partes adhiriéndonos a la clasificación que hacen Goldschmidt ${ }^{26}$ y, más recientemente, Ortells Ramos y Martín Pastor ${ }^{27}$, sin perjuicio de las demás catalogaciones existentes sobre los actos procesales de parte ${ }^{28}$.

\footnotetext{
${ }^{26}$ Goldschmidt (1936a), pp. 227 y 228, clasifica los actos de las partes en actos de postulación y constitutivos. Explica que "actos de postulación (Erwinkungshandlungen) son los que tienen por fin el conseguir una resolución judicial de determinado contenido, mediante influjos psíquicos ejercidos sobre el juez. Actos de esta clase son las solicitudes, afirmaciones (alegaciones) y aportaciones de prueba; y actos constitutivos (Bewinkungshandlungen) son todos los demás. Estos actos están siempre en una relación de finalidad con los actos de postulación ya realizados, o que habrán de realizarse, y son de tal clase los convenios (por ej., prorrogación de la competencia, compromiso y transacción), las declaraciones unilaterales de voluntad (por ej., el desistimiento de la demanda o del recurso, la asunción de un proceso del causante, el consentimiento para la modificación de la demanda, la renuncia al recurso, el otorgamiento de poder procesal, la ratificación de actos procesales), las participaciones de voluntad (los requerimientos, como, por ej., el de que se nombre abogado, la citación, el anuncio del propósito que se tiene de continuar el procedimiento, las denegaciones, así como también la renuncia a la acción, el allanamiento y la confesión), los avisos de hechos (por ej., la litis denunciación, anuncio de la extinción del poder o del nombramiento de un nuevo abogado o representante legal) y los llamados 'actos reales' (por ej., exhibición o retirada de un documento, aportación de medios de prueba)"

${ }^{27}$ Ortells y Martín (2011), pp. 401 y ss., clasifican los actos de parte en actos destinados a obtener una resolución judicial, dentro de los cuales alude a las peticiones, alegaciones, aportaciones de prueba y las conclusiones; y aquellos actos creadores de situaciones procesales.

${ }^{28}$ Entre las diversas clasificaciones de los actos procesales Colombo (1997), t. II, pp. 353-361; Pотtstock (1997), t. II, pp. 100-121; Carnelutti (1944), t. III, pp. 1-604, Carnelutti (1973), vol. I, pp. 427-455;
} 
Según explica Goldschmidt, los actos de postulación deben ser examinados en cuanto a si son o no admisibles y si están o no fundados. La admisibilidad dice relación con su contenido y la determina el derecho procesal; la fundabilidad tiene relación con si son apropiados para conseguir su finalidad y la determina el derecho material. Respecto de los actos constitutivos el autor sostiene que debe examinarse si son o no atendibles, es decir, si son eficaces o no desde el punto de vista procesal ${ }^{29}$.

Los típicos actos de postulación como la demanda, la contestación, la réplica y la dúplica, deben ser calificados de admisibles o inadmisibles por el juez. Esta valoración se refiere a una admisibilidad procesal y no de fondo, pues, esta última dependerá de la observancia de los presupuestos procesales, la inexistencia de óbices que impidan un pronunciamiento de mérito, de la prueba de los hechos constitutivos de la pretensión y del cumplimiento de las condiciones de la acción.

En otras palabras, en todos los actos de postulación ya sean peticiones o solicitudes, alegaciones, aportación de prueba y, finalmente, las apreciaciones críticas sobre estas últimas, el juez debe detenerse a comprobar la admisibilidad de las mismas. La fundamentación de tales actos puede ser más o menos estricta. Así, por ejemplo, la solicitud de una medida precautoria deberá determinarse si es admisible teniendo en cuenta quien la pide y si es fundada demostrando que se cumplen los requisitos procesales básicos que la hacen procedente como el fumus boni iuris, el periculum in mora y, en su caso, la exigencia de caución (arts. 279 № 2, 298, 299 CPC). Lo mismo ocurrirá con los actos que tienen por objeto impugnar una resolución, en cuyo caso el ordenamiento jurídico dispone que deberán cumplir ciertos requisitos para que sean declarados admisibles.

Respecto de los actos constitutivos o de causación también es necesario que el juez realice un examen de admisibilidad, pues, estos actos igual tendrán que cumplir ciertos requisitos que establece el ordenamiento jurídico. Estos actos no tienen por objeto lograr el convencimiento del juez, sino vincularlo a que resuelva de una determinada manera. En tal categoría pueden agruparse, entre otros, el desistimiento de la demanda, el allanamiento, la admisión de hechos, la confesión, la designación de domicilio ad litem, un acuerdo de suspensión del procedimiento. Estos ejemplos son típicos actos constitutivos o de causación, en virtud de los cuales, el juez queda vinculado a resolverlos de una determinada forma, siendo también necesario un examen de admisibilidad de los mismos.

Michel (1970), t. I, pp. 292-293; Alsina (1963), t. I, pp. 613-615; SATTA (1971), t. I, pp. 197-245; Guasp (2002), t. I, pp. 277-316; Palacio (1991), pp. 321-368; Couture (2011), pp. 166-171.

${ }^{29}$ Goldschmidt (1936a), p. 228, (la cursiva es nuestra). 
En consecuencia, la inadmisibilidad es predicable de todos los actos procesales que emanan de las partes y de terceros técnicos, pues, todos ellos deben ser valorados por el juez, no encontrando razones para diferenciar los actos de postulación de los de causación ${ }^{30}$.

\subsection{La calificación de admisibilidad-inadmisibilidad se realiza antes que el acto de parte o de terceros técnicos produzca efectos en el proceso}

La calificación de admisibilidad de un acto de parte o de terceros en sentido técnico se realiza cuando éstos quieren ejercer un determinado derecho o introducir o incorporar al proceso un determinado acto procesal ${ }^{31}$. Presentado el escrito en aquellos sistemas imbuidos por la escrituración o, en su caso, propuesto y deducido el acto en un proceso inspirado en la oralidad, el juez debe detenerse a calificarlo, pudiendo declararlo admisible o inadmisible.

El acto procesal que emana de las partes o de terceros técnicos no despliega sus efectos automáticamente por el hecho de haberse propuesto. Tales efectos solo nacerán en virtud de la declaración de admisibilidad del acto que estará contenida explícita o implícitamente en una resolución judicial.

La inadmisibilidad, entonces, se trata de un juicio o calificación jurídica del acto procesal de parte o de terceros técnicos que se realiza tan pronto como este se incorpora al proceso escrito $u$ oral, es decir, antes que el acto produzca efectos ${ }^{32}$.

\subsection{La declaración de inadmisibilidad impide que el acto procesal produzca sus efectos}

Esta característica de la inadmisibilidad deriva de la anterior, pues el análisis jurídico del acto se realiza ex ante o ab initio, es decir, previamente a que el

\footnotetext{
${ }^{30}$ En este sentido ANDRÉs (2005), p. 224, afirma que: "entendemos que todos los actos de parte son susceptibles de previa valoración por el juez en cuanto a su idoneidad para desplegar su eficacia. Esto que parece claro respecto de los actos de postulación, tampoco debe plantear dudas respecto de los actos de causación". También HeRnÁndez (1995), p. 106. En el mismo sentido haciendo aplicable la inadmisibilidad a todos los actos que provengan de las partes sin distinción alguna Creus (1995), pp. 116 y ss.; Otranto et al (2005), p. 424; Maurino (2001), p. 21; Palacio (1972), pp. 146-147.

31 Molina (2007), p. 23.

${ }^{32}$ Creus (1995), p. 116, expresa que: "la inadmisibilidad se presenta así como sanción previa al acto, mejor dicho, previa a la introducción del acto en el proceso (antes de que se convierta propiamente en acto procesal); se trata, pues, de una declaración de invalidez para el futuro, puesto que cuando se produce, el acto no ha suscitado efecto procesal alguno...". No estamos de acuerdo con lo que sostiene este autor, pues, no se trata de una declaración de invalidez para el futuro, pues el acto procesal ya existe por el hecho de haberse incorporado al expediente o por el hecho de proponerse en la audiencia oral. Distinto es que la producción de efectos del acto de parte dependa de la declaración que lo admite, pero no por tal razón se va a sostener que el acto aún no es acto procesal porque no ha producido efectos.
} 
acto produzca efectos; mientras no se lleve a cabo la calificación de admisibleinadmisible, el acto no produce ningún efecto.

Esto es sin perjuicio que todo acto procesal de parte por el solo hecho de presentarse genera ciertos efectos mínimos, como que el juez esté obligado a proveerlo ${ }^{33}$, deber que deriva del principio de inexcusabilidad (art. 76 CPR).

\subsection{Los defectos que motivan la inadmisión de un acto pueden ser subsanables e insubsanables}

La posibilidad de subsanación o corrección del acto defectuoso no siempre es posible ${ }^{34}$.

En nuestro sistema de enjuiciamiento civil, la posibilidad de subsanar un acto de parte que fue declarado inadmisible se presenta en aquellas hipótesis en que esta sanción actúa fomentando la aplicación del principio informativo de economía procesal y para una eficaz administración de justicia. Esta posibilidad de subsanación se presenta por regla general en los actos que tienen por objeto iniciar un proceso.

La inadmisibilidad del acto de parte, sin posibilidad ulterior de corrección del defecto, en cambio, está motivada ya sea para limitar la utilización de ciertos mecanismos procesales, ya sea para determinar de la viabilidad de la pretensión o del recurso impetrado, en los cuales basta la inobservancia de un determinado requisito que exige el ordenamiento jurídico para que se inadmita el acto, perdiendo o precluyendo, consecuencialmente, la oportunidad de proponerlo nuevamente de manera correcta en el proceso.

En algunos casos la corrección, subsanación o reproposición del acto objeto de la inadmisión, dependerá de que no se haya agotado, caducado o precluido tal posibilidad. De esta manera, la subsanación del acto declarado inadmisible, solo puede ocurrir mientras se mantenga vigente la posibilidad de actuar del sujeto procesal, sin perjuicio de las hipótesis que no tienen aparejadas un plazo determinado para subsanar el defecto ${ }^{35}$.

Para determinar si se trata de una hipótesis de inadmisibilidad con o sin posibilidad de subsanación posterior, habrá que estudiar cada caso concreto y determinar la finalidad de esta especial forma de invalidez. Sobre este punto volveremos mas adelante.

\footnotetext{
33 ANDRÉs (2005), p. 224.

${ }^{34}$ Sobre esta clasificación ROMERO (2017), pp. 52-54.

${ }^{35}$ Creus (1995), p. 124.
} 


\subsection{La inadmisibilidad es una sanción distinta de la nulidad procesal}

La inadmisibilidad se diferencia de la nulidad procesal ${ }^{36}$ en cuanto al objeto sobre que recae, al momento en que se produce el juicio o calificación de irregularidad y en cuanto a los efectos que genera la aplicación de ambas sanciones ${ }^{37}$.

En primer lugar, la inadmisibilidad constituye un mecanismo de calificación de regularidad procesal que recae o ejerce respecto de los actos procesales que emanan de las partes y terceros técnicos; la nulidad procesal, en cambio, constituye un juicio de valor de las consecuencias perjudiciales causadas a alguna de las partes por haberse infringido sus derechos o garantías procesales, aplicable a los actos irregulares o defectuosos que provienen del órgano jurisdiccional o de terceros metajurídicos ${ }^{38}$.

En segundo lugar, el juicio de admisibilidad-inadmisibilidad se realiza $a b$ initio, en el momento en que el acto de parte se incorpora al proceso; la calificación de nulidad, cambio, se ejerce ex post, una vez que el acto procesal o la actuación ha sido incorporada al proceso, por lo que la irregularidad invalidante se observa una vez que el acto se ha insertado en el proceso, después que ha desplegado sus efectos.

En tercer lugar, la declaración de inadmisibilidad impide la producción de efectos del acto procesal; en cambio, la declaración de nulidad elimina, destruye o extirpa los efectos generados por el acto inválido que al momento de declararse la nulidad deviene en ineficaz.

En consecuencia, como se ha demostrado, se trata de sanciones distintas, que difieren en cuanto al ámbito de aplicación, en las funciones asignadas por la ley $y$ en los efectos que generan.

\subsection{Las hipótesis de inadmisibilidad responden a causales variadas y funciones heterogéneas}

Las causales de inadmisibilidad y su tratamiento procesal, en cuanto exista la posibilidad de volver a proponer correctamente el acto inadmitido, dependen de la finalidad o función que el ordenamiento jurídico asigne a esta sanción.

El análisis limitado de las hipótesis más relevantes de inadmisibilidad, nos permite sistematizar sus causales en tres grupos, a saber: (i) la inadmisibilidad

\footnotetext{
${ }^{36}$ Algunos autores señalan que se trata de una forma de hacer valer la nulidad. En este sentido MAIER (1980), p. 141; BeDAQue (2010), p. 714.

${ }^{37}$ Estas diferencias las expresa Creus (1995), p. 10. En este mismo sentido Otranto et al (2005), p. 424.

${ }^{38}$ Sobre la nulidad procesal como juicio de valor Bordalí (2016), pp. 389 y ss.; Gorigortía (2013), pp. 139 y ss.; CARRASCO (2015), p. 17.
} 
como sanción transitoria, con posibilidad de subsanar el acto inadmitido, contra los actos de iniciación del proceso que infringen requisitos formales; (ii) la inadmisibilidad como sanción permanente, sin posibilidad de subsanar el acto inadmitido, contra actos procesales que no observan alguno de los requisitos que dispone el ordenamiento; y (iii) la inadmisibilidad como sanción destinada a declarar la inviabilidad de la pretensión o de un recurso.

Las razones que motivan la inadmisibilidad dependen de cada caso concreto, no obstante, se pueden mencionar a modo genérico, las siguientes: el principio de economía procesal, la correcta administración de justicia, la limitación o restricción de ciertos mecanismos procesales potencialmente saturados y el fomento de la buena fe procesal. Estas funciones serán analizadas a continuación.

\section{Las múltiples funciones actuales que puede asignarse a la admisibilidad- inadmisibilidad en el proceso civil}

En la actualidad, la admisión no puede ser estudiada solo desde su explicación clásica, porque del análisis de los diversos preceptos legales puede extraerse otros fines para dicha institución. En efecto, contemporáneamente la admisión-inadmisión puede explicarse aludiendo a otras funciones, entre otras, como un instrumento de economía procesal; como un filtro para la interposición de un recurso; como una posible respuesta a los abusos de presentaciones de escritos sin cumplir los requisitos que dispone la ley. Para vislumbrar los fines que se asigna a la inadmisibilidad, basta echar una mirada a las hipótesis comprendidas en nuestro ordenamiento jurídico, principalmente las del Código de Procedimiento Civil, cuestión que desarrollaremos a continuación ${ }^{39}$.

\subsection{La inadmisibilidad como sanción transitoria, con posibilidad de subsanar el acto inadmitido, contra los actos de iniciación del proceso que infringen requisitos formales}

Dentro de este criterio, podemos encontrar varias hipótesis de inadmisibilidad.

Así sucede, por ejemplo, cuando no se observa por el demandante los requisitos legales para presentar la demanda previstos en los números 1, 2 y 3 del artículo 256 CPC. En este evento, el ordenamiento dispone que puede el juez de oficio no dar curso a la demanda que no contiene las indicaciones precedentes, señalando el defecto de que adolece (art. 256 CPC).

Esta misma hipótesis ocurre tratándose de una demanda ejecutiva que pretenda cobrar una cantidad de dinero expresada en moneda extranjera, pues, al

\footnotetext{
${ }^{39}$ Para poder entregar mayores ejemplos en ciertos casos nos referiremos a disposiciones e hipótesis de admisibilidad contenidas en otros Códigos o leyes especiales.
} 
demandante le corresponde, para efectos de determinar la cuantía de la obligación, acompañar los documentos que sean necesarios para ese fin, de acuerdo con lo dispuesto por los artículos 21 y 22 de la Ley № 18.010 y 116 y 120 del COT.

Dentro de este criterio hemos incluido también la constitución indebida del poder o mandato judicial (art. $2^{\circ}$ inc. $4^{\circ}$ Ley $N^{\circ} 18.120$ ). Sin embargo, se trata de un caso especial porque el ordenamiento dispone de un plazo legal y fatal, dentro del cual la parte debe constituir debidamente el poder, bajo apercibimiento que, si no lo hace, la actuación se tendrá por no presentada para todos los efectos legales.

También caben dentro de este criterio algunas de las causales en virtud de las cuales el juez de garantía puede declarar inadmisible la querella. En efecto, las causales de las letras a) y b) del artículo 114 del CPP dicen relación con cuestiones de forma por lo que basta que falte alguno de los requisitos señalados en dichos literales para que la querella sea declarada inadmisible.

Todas estas disposiciones a las que aludimos precedentemente constituyen hipótesis de inadmisibilidad momentáneas o transitorias, pues, basta que la parte que realizó el acto irregular corrija el defecto, para que, posteriormente, el juez se pronuncie admitiendo el acto procesal, declarando la subsanación del defecto $y$, en consecuencia, confiera traslado u ordene el despacho de la ejecución, según corresponda.

Un caso especial lo constituye incurrir en el apercibimiento dispuesto por la ley cuando no se constituye debidamente el mandato judicial. Esta hipótesis, en principio, se trata de un caso de inadmisibilidad subsanable, pero si no se corrige el defecto dentro del plazo perentorio, se hará efectivo el apercibimiento, mutando la sanción a una caducidad, impidiendo su corrección o subsanación posterior, fundado en razones de economía procesal y eficiente administración de justicia.

Sostenemos que la admisión-inadmisión, en la etapa de iniciación del proceso con posibilidad de subsanación del defecto, obedece a razones de economía procesal, pues, se evita un desgaste de tiempo, de recursos económicos y técnicos al impedir que un proceso avance sin que cumpla los requisitos que exige la ley.

En esta orientación, se entienden los mecanismos procesales que tienen por objeto subsanar los defectos de ciertos actos como, por ejemplo, la interposición de excepciones procesales o dilatorias con el objeto de corregir la inobservancia de presupuestos y óbices procesales para la correcta configuración de la litis, o en los sistemas procesales informados por la oralidad, el establecimiento de audiencias preparatorias o previas a las cuales se asignan objetivos similares ${ }^{40}$.

\footnotetext{
${ }^{40}$ Así lo explica Palomo (2010), pp. 47-48; el mismo autor (2008), pp. 213 y ss.
} 
La inadmisión en estos casos juega un papel importante como un mecanismo sancionatorio, que tiene por objeto declarar la invalidez de un acto de parte o de terceros en sentido técnico que, de no controlarse oportunamente, genera graves repercusiones en etapas posteriores del proceso. Este control in límine, en su etapa inicial, es correcto porque permite depurar formalmente el proceso ${ }^{41}$, impidiendo transitoriamente su avance hasta que se resuelvan las cuestiones procesales que obstan a la prosecución del proceso ${ }^{42}$, incorporando una técnica subsanatoria de los actos defectuosos que tienen su origen en las partes o terceros técnicos, logrando que en una etapa posterior y final se pronuncie una sentencia de mérito que resuelva el fondo de la controversia, evadiéndose las denominadas sentencias absolutorias en la instancia, fomentando la eficiencia del proceso inserta en el tan clásico principio informativo de economía procesal ${ }^{43}$.

\subsection{La inadmisibilidad como sanción permanente, sin posibilidad de subsanar el acto inadmitido, contra actos procesales que no observan alguno de los requisitos que dispone el ordenamiento}

El ordenamiento jurídico, en ciertos casos, sanciona drásticamente ciertos actos de parte o de terceros en sentido técnico que no cumplen ciertos requisitos legales.

La sanción en estos casos es más rigurosa, porque impide que la fuente generadora del acto pueda subsanar el vicio, incurriendo derechamente en una declaración de inadmisibilidad del mismo.

Estos casos de inadmisibilidad, por lo general, se generan cuando un determinado acto no cumple con los requisitos que dispone la ley. Así sucede, por ejemplo, en el evento que el ejecutado no relate las excepciones opuestas contra la ejecución con la claridad y precisión necesaria para su comprensión (art. 465 CPC) ${ }^{44}$; cuando no se observan las exigencias legales para impetrar

\footnotetext{
${ }^{41}$ En este sentido HUNTER (2009), p. 120.

${ }^{42}$ Así lo destaca Gimeno (2007), pp. 245-246, al señalar que: "en un proceso moderno es siempre recomendable que el tratamiento de tales presupuestos se haga a limine litis, esto es, al inicio del proceso y no al final de la fase declarativa o al término de algunas de sus instancias, ya que, si así aconteciera, el actor habrá perdido el tiempo y su dinero, pues el contenido de tales resoluciones se circunscribe a declarar la ausencia del presupuesto procesal, dejando imprejuzgada la relación jurídico-material debatida...". Berizonce (1993), pp. 452 y ss.; FaIRÉN (1955), pp. 448 y ss.

${ }^{43}$ CierCo (2009), pp. 42-43.

${ }^{44}$ Así, entre otras, la sentencia de la CS. 1 de octubre de 1925, RDJ., t. XXIII, sec. $1^{\text {a }}$, pp. 477 y ss., (considerando $5^{\circ}$ ), resolvió que: "... los fundamentos de las excepciones que el ejecutado puede oponer, conforme al artículo 486 del Código de Procedimiento Civil, caracterizan o determinan las excepciones de tal modo, que según sean ellas, así también será la clase o especie de excepción de-
} 
los recursos de apelación, casación en la forma, casación en el fondo y nulidad (arts. 201 inc. $1^{\circ}, 205$ inc. $1^{\circ}, 213$ inc. $2^{\circ}, 466$ inc. $3^{\circ}, 778$ inc. $1^{\circ}, 781$ inc. $2^{\circ}$ todos del CPC y 383 del CPP).

En estas hipótesis se mezclan diversos requisitos legales, cuyo incumplimiento importa la declaración de inadmisibilidad. Preliminarmente, estas exigencias pueden sintetizarse en que la inadmisión está motivada tanto por cuestiones de forma como de contenido de los actos procesales, incluyéndose en casi todas las hipótesis legales, la inobservancia de la oportunidad procesal para ejecutar o realizar un determinado acto.

A propósito del recurso de apelación, como se sabe, este debe interponerse dentro de la oportunidad legal que corresponde; la naturaleza de la resolución judicial debe ser susceptible de apelarse; el recurso debe ser fundado y contener un petitum concreto. En el evento que no se cumplan estas exigencias tanto el juez a quo como el tribunal ad quem pueden declarar inadmisible el referido recurso (arts. 201 inc. $1^{\circ}$ y 213 inc. $2^{\circ} \mathrm{CPC}$ ) ${ }^{45}$. En dicho caso, la resolución impugnada quedará firme y procederá la devolución del proceso si este se elevó (art. 205 inc. $1^{\circ} \mathrm{CPC}$ ).

Tratándose de los recursos de casación en la forma y en el fondo, el ordenamiento jurídico también dispone el cumplimiento de ciertos requisitos para que aquellos sean declarados admisibles.

Respecto de la casación en la forma, la resolución impugnada debe tener una naturaleza que haga posible la interposición de este recurso (art. 766 CPC); el recurrente debe indicar una causal legal que lo haga procedente (arts. 768 inc. $1^{\circ}$ y 772 inc. $2^{\circ} \mathrm{CPC}$ ); debe existir un perjuicio trascendente solo reparable a través de la invalidación o que influya en lo dispositivo del fallo (art. 768

ducida en el juicio; por lo que no basta enunciar alguna de las que genéricamente enumera aquella disposición legal para que se la admita a tramitación y recaiga un pronunciamiento sobre ella, sino que debe determinársela y concretársela con la exposición de los hechos, antecedentes o motivos que manifiesten la fisonomía jurídica propia". Sobre esto también véase CA. de Santiago, 27 de enero de 1993, RDJ., t. XC, sec. $2^{\text {a }}$, págs. 14 y ss. (considerandos $1^{\circ}$ y $2^{\circ}$ ). Otra sentencia de la CS. 9 de enero de $1937, R D J .$, t. XXXIV, sec. $1^{\text {a }}$, págs. 184 y ss., (considerandos $1^{\circ}$ y $2^{\circ}$ ), resolvió que: "el ejecutado (...) al decir en el otrosí de su escrito de excepciones que 'usará en la ejecución de todos los medios probatorios que le acuerda la ley a excepción de la prueba de testigos' ha cumplido debidamente con la exigencia contemplada en el artículo 487 del Código de Procedimiento Civil (...).- 2. ${ }^{\circ}$ Esta interpretación se ajusta a la letra y al espíritu del Código Procesal, que, en sus disposiciones, salvo casos muy especiales no exige al litigante usar fórmulas o términos sacramentales (...)".

${ }^{45}$ En este sentido, CS. 21 de enero de 2010, rol № 6853-2008, (Cita Legal Publishing: CL/JUR/726/2010), (considerando $6^{\circ}$ ); CA. de Santiago, 17 de enero de 2007, rol № 2925-2006, (Cita Legal Publishing: CL/JUR/6683/2007), (considerando 3); CA. de Santiago, 26 de agosto de 2010, rol № 67882009, (Cita Legal Publishing: CL/JUR/12014/2010), (considerandos $6^{\circ}, 8^{\circ}$ y $10^{\circ}$ ); CA. de Santiago, 1 de septiembre de 1998, GJ., 219, 1998, págs. 237-238, (considerando $3^{\circ}$ ), (la misma sentencia en Cita Legal Publishing: CL/JUR/1511/1998); CA. de Talca, 9 de agosto de 1991, rol № 44274-1989 (Cita Legal Publishing: CL/JUR/448/1991). 
inc. $3^{\circ} \mathrm{CPC}$ ); el recurrente debió preparar el recurso e interponerlo dentro de la oportunidad procesal (arts. 769 y 770 CPC) y, finalmente, el recurso debe cumplir un requisito de ius postulandi al tener que ser patrocinado por abogado habilitado que no sea procurador del número (art. 772 inc. $3^{\circ} \mathrm{CPC}$ ).

Con respecto a la casación en el fondo, la resolución recurrida debe tener una naturaleza que haga susceptible la interposición de este recurso (art. 767 $\mathrm{CPC})$; el recurrente debe expresar el error de derecho en que incurre la sentencia recurrida y explicar la manera en que dicho error influye sustancialmente en lo dispositivo del fallo (art. 772 inc. $1^{\circ} \mathrm{N}^{\circ}$ s. 1 y $2 \mathrm{CPC}$ ); el recurrente debe interponerlo dentro de la oportunidad procesal (arts. 770, 776, 781 CPC) y, finalmente, el recurso también debe cumplir un requisito de ius postulandi al tener que ser patrocinado por abogado habilitado que no sea procurador del número (art. 772 inc. $3^{\circ} \mathrm{CPC}$ ).

A nivel jurisprudencial se han agregado una serie de requisitos para que el recurso de casación en el fondo no sea rechazado, así por ejemplo, entre otras, que la norma jurídica que se denuncia como infringida debe calificar dentro del concepto de ley; la debida utilización del plural a la hora de indicar el patrocinio del recurso; que no se invoquen subsidiaria o conjuntamente los motivos de casación; que el recurso sea deducido por una parte del juicio; que no se denuncie por vía de casación en el fondo una cuestión jurídica que debió ser reclamada por la vía de la casación en la forma; que el error de derecho que autoriza la invalidación del fallo guarde relación de causa a efecto con lo resolutivo de la sentencia, causando perjuicio procesal al recurrente ${ }^{46}$.

Finalmente, en materia procesal penal se contempla un recurso extraordinario de nulidad el cual debe cumplir ciertos requisitos como son su interposición dentro de la oportunidad que dispone la ley y por escrito (art. 372 CPP); dependiendo de la causal legal en que se funde el recurso se debió haber preparado (art. 377 CPP); debe estar fundado y contener peticiones concretas (art. 378 CPP). El estudio de admisibilidad del juez a quo solo dirá relación con su interposición contra resolución cuya naturaleza sea susceptible de impugnarse por esta vía (art. 372 CPP) y que el recurso se haya impetrado dentro de plazo (art. 380 CPP). El estudio de admisibilidad del tribunal ad quem es más riguroso, de acuerdo a lo dispuesto en el artículo 383 del CPP, pudiendo declararlo inadmisible si carece de fundamentos de hecho y de derecho, si no contiene peticiones concretas y si no fue preparado.

En todas las hipótesis aludidas precedentemente, la inobservancia de tan solo uno de los requisitos mencionados (de forma o contenido del acto) importa la declaración de inadmisibilidad del recurso, no contemplándose por el

${ }^{46}$ Sobre estos requisitos ROMERO et al (2008), pp. 230-254. 
ordenamiento jurídico manera alguna de subsanar posteriormente el defecto que adolece el acto de parte o de terceros técnicos.

Las razones que motivan este proceder consisten en lograr una descongestión de ciertos causes procesales que pueden ser saturados, los cuales se vislumbran especialmente en el ámbito de los recursos o medios de impugnación. En efecto, nuestro sistema procesal civil presenta dos grados jurisdiccionales (doble instancia) en los cuales se pueden discutir y revisar tanto los hechos como el derecho, sin perjuicio que posteriormente se puede impetrar los recursos de casación en la forma y en el fondo.

En este contexto, el ordenamiento jurídico pretende a través de la inadmisión descongestionar un determinado mecanismo procesal que se satura fácilmente, como son los medios de impugnación, utilizando la sanción denominada inadmisibilidad, la que actuará cuando las partes o terceros técnicos impugnen una determinada resolución judicial sin observar las exigencias que indica el ordenamiento jurídico.

Esta finalidad de descongestión o desahogo de ciertos instrumentos procesales impide que los actos defectuosos que se declaran inadmisibles puedan, posteriormente, subsanarse o corregirse. En este sentido la calificación de validez-invalidez del acto se produce ex ante; en caso que el acto no observe los requisitos que dispone el ordenamiento se declarará su inadmisibilidad, impidiendo la producción de efectos del mismo.

\subsection{La inadmisibilidad como sanción destinada a declarar la inviabilidad de la pretensión o de un recurso}

La inadmisibilidad también puede tener por objeto declarar la inviabilidad de una pretensión o de un determinado recurso.

En el primer caso se ubica la hipótesis contenida a propósito de la acción de protección, en el evento que quien lo interpone no señale los hechos que puedan constituir la vulneración de garantías constitucionales, o si la acción se interpone extemporáneamente (art. $2^{\circ}$ inc. $2^{\circ} \mathrm{AA}$. de la CS. sobre tramitación del recurso de protección de garantías constitucionales).

La tramitación de la acción de protección se regula en el Auto Acordado de la Corte Suprema, de 24 de junio de 1992, sobre tramitación del recurso de protección de garantías constitucionales, el que ha sufrido diversas modificaciones, dentro de las cuales destaca la sustitución del inciso $2^{\circ}$ del artículo $2^{\circ}$, que en su redacción actual expresa que: "presentado el recurso el Tribunal examinará en cuenta si ha sido interpuesto en tiempo y si se mencionan hechos que puedan constituir la vulneración de garantías de las indicadas en el artículo 20 de la Constitución Política de la República. Si su presentación es extemporánea o no se señalan hechos que puedan constituir vulneración a las garantías mencionadas en la referida disposición constitucional, lo declarará 
inadmisible desde luego por resolución fundada, la que solo será susceptible del recurso de reposición ante el mismo tribunal, el que deberá interponerse dentro de tercero día" ${ }^{47}$.

Consideramos que la modificación del auto acordado tuvo por objeto limitar la interposición infundada de acciones de protección. Esta restricción se produce estableciendo condiciones más rígidas, en donde se incorpora al inicio de la tramitación de la referida acción, un trámite de admisión ad-hoc que constituye un verdadero filtro que protege el abuso o el uso irreflexivo de esta acción cautelar ${ }^{48}$. Sin embargo, este control de admisibilidad también puede constituir una limitación del derecho de acción, toda vez que de manera previa, una sala de la respectiva Corte y sin referirse al fondo de la cuestión, podrá determinar si la acción cautelar es admitida a tramitación ${ }^{49}$.

Dentro del primer caso, también consideramos que se encuentra la calificación de admisibilidad-inadmisibilidad a que deben someterse las acciones que protegen intereses supraindividuales ${ }^{50}$, contenidos en la Ley de Protección de los Derechos de los Consumidores (arts. 52 de la Ley No 19.496). A nuestro entender, los requisitos que dispone el artículo 52 de la referida ley, se refiere a una calificación que mezcla diversas exigencias que deben estar presentes en la demanda que contiene la acción colectiva o difusa, las que dicen relación

\footnotetext{
${ }^{47} \mathrm{El}$ inciso $2^{\circ}$ del art. $2^{\circ}$ del AA. mencionado fue sustituido por el que aparece en el texto, por el $N^{\circ}$ 1, letra b) del AA. de 25 de mayo de 2007, publicado en el Diario Oficial de 8 de junio de 2007 y que entró a regir el 1 de julio de 2007.
}

${ }^{48}$ Cierco (2009), p. 45.

${ }^{49}$ Las críticas al trámite previo de admisibilidad de la acción de protección se manifestaron desde hace tiempo en la doctrina. Las primeras tuvieron por objeto objetar las modificaciones introducidas por el Auto Acordado dictado por la Corte Suprema, el 4 de mayo de 1998, en el cual se facultó a las Cortes de Apelaciones para declarar en cuenta la inadmisibilidad de esta acción, si el Tribunal estima en opinión unánime de la sala que su interposición es extemporánea o carece de manifiesta falta de fundamento, pudiendo ser impugnada esa resolución a través de la solicitud de reposición. Sobre estas críticas Soto (1998), pp. 273-278; Saenger (1998), pp. 259-271; Bruna (1998), p. 134; Ferrada et al. (2003), pp. 78-79. Con respecto a la modificación efectuada en 2007 (Diario Oficial de 8 de junio de 2007), Sото (2009), p. 521, expresa que “... tal trámite -aun si aparentemente 'aligerado'- es derechamente inconstitucional, puesto que viola, vulnera y avasalla el derecho natural y fundamental, constitucionalmente reconocido de modo expreso, de acceso a la justicia, juntamente con los derechos fundamentales del derecho de acción, del derecho a la tutela judicial efectiva y del derecho al debido proceso, derechos todos que son directamente afectados en su 'contenido esencial' ('en su esencia').Ello, desde que-incluso sin audiencia del afectado-se impide, a través de él, que un tribunal, y tribunal superior, conozca de una pretensión, de su competencia, que se le formula de acuerdo a Derecho, para que ampare un derecho fundamental que una persona ve, en su legítimo ejercicio, agraviado por un acto u omisión, que se estima antijurídico, de un tercero, quienquiera sea éste". En el mismo sentido PINOCHET (2013), p. 306-307.

${ }^{50}$ Sobre el concepto de interés supraindividual y la diferencia entre intereses colectivos y difusos Aguirrezábal (2013a), pp. 967-976; Cortez (2013), pp. 951-966. 
con aspectos de fondo y no meramente formales, como son, en síntesis, que sea deducida por personas legitimadas; que se afecte el interés colectivo o difuso de los consumidores en los términos señalados en el artículo 50; y que el número potencial de afectados justifique, en términos de costos y beneficios, la necesidad procesal o económica de someter su tramitación a este procedimiento especial ${ }^{51}$.

Consideramos que la calificación de admisible o inadmisible dice relación con aspectos de fondo, lo cual en principio no debiera ocurrir, sin embargo, consideramos que lo que pretende el ordenamiento jurídico es controlar la viabilidad de las acciones colectivas o difusas.

Otra hipótesis que podemos mencionar está contenida en el artículo 54-1 inciso $3^{\circ}$ de la Ley $\mathrm{N}^{\circ} 19.968$, al disponer un control de admisibilidad de la demanda, denuncia o requerimiento presentado en un Tribunal de Familia, si se estima que la presentación es manifiestamente improcedente. Como se aprecia, se trata de un control sobre la procedencia o si es proponible la pretensión, debiendo el juez examinar si lo solicitado por la parte es posible de ser tutelado por el órgano jurisdiccional de familia ${ }^{52}$.

En el segundo caso, se ubica la hipótesis relativa al recurso de casación en el fondo, que dice relación con el examen de inviabilidad de dicho recurso cuando, no obstante cumplirse todos los requisitos que disponen el inciso $1^{\circ}$ de los artículos 772 y 776 CPC, en opinión unánime de la sala, deciden rechazarlo de inmediato por adolecer de manifiesta falta de fundamento (art. 782 inc. $\left.2^{\circ} \mathrm{CPC}\right)$.

Las razones que motivan esta manera de proceder de la Corte parecieran ser las mismas que acarrean la inadmisión del recurso de protección, esto es, limitar el ingreso a la Corte Suprema de innumerables recursos de casación en el fondo que se interponen contra las resoluciones dictadas en segunda instancia. Sin embargo, tales potestades que detentan los jueces, en ciertas ocasiones pueden infringir el derecho al debido proceso y el acceso a los medios de impugnación que franquea la ley (derecho al recurso), debiendo utilizarse con un cuidado muy riguroso. Consideramos que en caso de duda,

\footnotetext{
${ }^{51}$ Aguirrezábal (2013), pp. 1027 y ss.; AguirrezÁbal (2014), pp. 81-86.

${ }^{52}$ JARA (2014), p. 145, explica que "no es posible sostener que este control preventivo pretende decidir sobre la procedencia de la pretensión; o sea, si esta será en definitiva acogida o rechazada". Según expresa el mismo autor, "en la discusión de la historia de la Ley № 20286, donde el abogado de la División jurídica del Ministerio de Justicia, señor Rodrigo Zúñiga, expresó: 'que la inserción en la Ley № 19.968 de este nuevo párrafo es de la mayor importancia. Explicó que el trámite de admisibilidad previo recoge la persistente demanda de los jueces de familia, en orden a instalar un filtro al inicio de los procesos, que permita descartar asuntos manifiestamente improcedentes porque no son judiciables o no son de su competencia. Sin esta herramienta depuradora los tribunales de familia están obligados a tramitar el juicio y a rechazar el asunto en la sentencia, con carga adicional de trabajo y pérdida de tiempo consiguientes".
} 
deberá fomentarse y preferirse la declaración de admisibilidad o viabilidad fundado en el principio pro actione ${ }^{53}$.

\section{La inadmisibilidad vinculada al examen de fondo del asunto}

En la actualidad la inadmisión no solo se refiere a un juicio o calificación de cumplimiento de los requisitos de naturaleza procesal o formal de un acto de parte o de terceros técnicos, sino que ha evolucionado en cuanto a que existen hipótesis que permiten declarar inadmisible un acto atendiendo a un juicio o examen sobre el fondo del asunto ${ }^{54}$. En efecto, esto ocurre cuando cualquiera de las salas de la Corte Suprema, utilizando la prerrogativa contenida en el inciso $2^{\circ}$ del artículo 782, en el segundo estudio de admisibilidad, pueda rechazar de inmediato el recurso de casación en el fondo si en opinión unánime de sus integrantes, adolece de manifiesta falta de fundamento.

La doctrina ha establecido que el rechazo del recurso por manifiesta falta de fundamento se trata de un examen de fundabilidad y no de admisibilidad pues, según el tenor de la norma, el primero supone al segundo, y por lo mismo, no se trata de una causal de inadmisibilidad del recurso de casación en el fondo ${ }^{55}$. Sin embargo, en legislaciones comparadas existe el examen de admisibilidad del recurso de casación en el fondo civil por manifiesta falta de fundamento y esta inadmisión debe fundarse en el carácter manifiesto, palmario, evidente, a primera vista con que se evidencia la falta de fundamento. En conclusión, la causal de manifiesta falta de fundamento existente en legislaciones comparadas es la misma que expresa el art. 782 del CPC. La diferencia entre una u otra estriba en que la hipótesis que comentamos se explica como un examen de fundabilidad y no de inadmisibilidad, no obstante, los efectos de dicho examen en comparación a la inadmisibilidad son idénticos.

Por otro lado, en épocas pretéritas nuestra acción constitucional de protección incorporó la manifiesta falta de fundamento como causal de inadmisibilidad, por lo que resulta pertinente tratar esta hipótesis. En efecto, el Auto Acordado sobre tramitación de la acción de protección de 1992, modificado el año 1998, incorporó al inciso $2^{\circ}$ del $N^{\circ} 2$ la causal de inadmisibilidad ya mencionada. Si bien en la actualidad esa causal no se encuentra vigente producto de la modificación efectuada el 2007, sí se establece que la acción puede ser declarada

\footnotetext{
${ }^{53}$ Berizonce (2007), pp. 5-16.

${ }^{54}$ Dejamos muy en claro que cuando aludimos a la "inadmisibilidad de fondo o contenido del acto" nos referimos a aquella que no dice relación con simples requisitos formales del acto procesal, sino que el acto no sea idóneo, inviable o no pueda alcanzar el fin perseguido.

${ }^{55}$ En este sentido Tavolari (1996), p. 71; Mosquera y Maturana (2010), pp. 322 y ss.; Maturana (2015), t. II, pp. 814 y ss.; Palomo (2016), p. 346; Libedinsky (2011), t. II, pp. 991-998.
} 
inadmisible si se impetra extemporáneamente o si no se señalan hechos que puedan constituir vulneración a las garantías mencionadas en el artículo 20 de la Carta Fundamental. De esta manera, el examen de admisibilidad se refiere no solo a los requisitos formales de la acción de protección sino que también al fondo de la misma, a su viabilidad. En efecto, la única manera de analizar la viabilidad de la acción de protección es determinar si los hechos constituyen una vulneración de garantías constitucionales para lo cual resulta necesario calificar jurídicamente esos hechos.

Otra admisibilidad referida al fondo se encuentra a propósito de la calificación de admisibilidad-inadmisibilidad a que deben someterse las acciones que protegen intereses supraindividuales contenidas en la Ley de Protección de los Derechos de los Consumidores (arts. 52 de la Ley No 19.496). En efecto, la legitimación exigida se trata de una cuestión de fondo y no de forma, toda vez que es una condición o requisito de la acción y no un presupuesto procesal ${ }^{56}$. Lo mismo ocurre con el segundo requisito, es decir, que se afecte el interés colectivo o difuso de los consumidores en los términos señalados en el artículo 50 de esa Ley.

Por otro lado, también se ha declarado inadmisible una demanda ante un tribunal de familia, fundado en que la petición de cuidado personal compartido de los hijos es materia de una regulación mediante acuerdo entre los padres, cuando ellos viven separados, lo que debe materializarse en una escritura pública o en un acta extendida ante un oficial del Registro Civil, subinscrita al margen de la respectiva inscripción de nacimiento del hijo, dentro de los treinta días subsiguientes a su otorgamiento, no pudiendo intervenir un tribunal. Por lo cual, la demanda que intenta que el juez competente ordene el cuidado compartido es improponible, pues el juez solo está facultado para atribuir el cuidado personal a uno de los padres, pero no puede ordenar el cuidado compartido para ambos, ya que ello es materia de acuerdo entre estos ${ }^{57}$.

De esta manera, del estudio que hemos realizado queda en evidencia que el examen de admisibilidad-inadmisibilidad puede referirse no solo a los requisitos formales de un acto, sino que también de ciertos requisitos de fondo, a la viabilidad de la pretensión o de la acción o recurso interpuesto. Por lo mismo,

\footnotetext{
${ }^{56}$ Parte de la doctrina postula que la legitimación se trata de una cuestión de fondo fundada en que debe resolverse en la sentencia y, en consecuencia, que la legitimación constituye un presupuesto de la acción y no un presupuesto procesal. En este sentido ROMERO (2007), p. 93; CARRASCO y GARROTE (2011), pp. 151-158; Ortells (2007), p. 155; De la Oliva (1992), t. I, pp. 439-440; Prieto-Castro (1982), t. I, p. 323. En sentido contrario MONTERO (2009), pp. 35 y 113-114. En nuestro derecho adopta esta última posición BORDALí (2010), p. 234.

${ }^{57}$ Corte de Apelaciones de Concepción, 2 de septiembre de 2015, rol 364-2015.
} 
no sería insólito o novedoso que revisando otras disposiciones legales encontremos admisibilidades de fondo y no solo referidas a requisitos formales del acto.

\section{Los requisitos de admisibilidad, el derecho de acceso a la justicia y el derecho al recurso}

Las formas de los actos procesales evitan que las partes sean sorprendidas durante el proceso, imponiendo la existencia de una actitud leal entre las mismas, resguardando el respeto al principio de contradicción; a que las partes posean iguales posibilidades para ejercer sus derechos y defensas dentro del proceso $^{58}$. La infracción de tales derechos y garantías procesales, generará las sanciones que la ley establece para cada caso en concreto, otorgando seguridad a los litigantes ${ }^{59}$.

Uno de los problemas que puede provocar el excesivo establecimiento de requisitos de admisibilidad, dice relación con la afectación de derechos e intereses legítimos de las personas. En efecto, esta afectación se produce principalmente cuando en los actos de iniciación del proceso (actos de postulación) o en la etapa recursiva se impone el cumplimiento de una serie de requisitos que, finalmente, pueden afectar el derecho del justiciable a un debido proceso.

Como se sabe, el debido proceso como principio natural, incluye la posibilidad que todo justiciable efectivamente pueda acceder a los Tribunales de Justicia, con el objeto de impetrar tutela jurisdiccional de los derechos e intereses legítimos que considera vulnerados. En nuestra doctrina, se han utilizado

\footnotetext{
${ }^{58}$ En este sentido la jurisprudencia ha afirmado que "... las formalidades que establece la ley de la actuación en general, obedecen al propósito de resguardar los derechos de las partes, a fin de que dentro del proceso dispongan de medios eficaces para hacer valer sus derechos...". En este sentido CS, 25 de octubre de 1963, RDJ., t. LX, sec. 1ª pág. 316; CA. de Santiago, 13 de junio de 1997, RDJ., t. XCIV, sec. $2^{\text {a }}$, pág. 71, (considerando $3^{\circ}$ ).

${ }^{59} \mathrm{Al}$ respecto BONET (1981), pp. 206 y 206 sostiene que: "Y es que el litigante desde que decide dirigirse a un tribunal jurisdiccional debe saber cuáles van a ser todos los pasos y tiempos que será necesario cubrir para que su acción o excepción sea recibida a examen en la sentencia". En nuestra doctrina OBERG (2001), p. 199, afirma que las formas "... facilitan el proceso y le permiten al juez acceder a la verdad con mayor garantía. Asimismo, la preexistencia de las formas procesales avala una defensa igualitaria, ya que se conocen al iniciarse el proceso...". Sobre la necesidad de las formas procesales CHIOvenDA (1954), t. III, p. 116; LieBMAN (1980), p. 169. La forma no solo es importante en los actos de parte sino también en los actos que emanan del juez. En efecto la regulación de los actos del procedimiento, de las formalidades que éstos deben cumplir, imprime seguridad jurídica tanto a las partes como al juez, toda vez que el interesado conocerá la manera en que deben exteriorizarse los actos de los diversos intervinientes en el proceso y el juez sabrá que, al incumplir estas formas, sus resoluciones pueden causar un eventual perjuicio o agravio a las partes que abren la posibilidad de impugnarlas. Además, las formas procesales impuestas al órgano jurisdiccional impiden que la decisión que adopte sea influenciada por otros poderes, asegurando que esta será adoptada de manera independiente e imparcial y en la forma que la ley señale. En este sentido Calamandrei (1973), vol. I, p. 322; Martín (1996), p. 80; Arellano (2005), p. 75; Rubio de Orellana (1996), vol. I, pp. 194-195; Pallares (1991), p. 578.
} 
diversas expresiones para referirse a esta cuestión, por ejemplo, derecho de acción, derecho a la jurisdicción, derecho a la tutela efectiva ${ }^{60}$.

Independiente de la denominación que se quiera utilizar, convengamos que el derecho de acceso a la justicia consiste básicamente en el derecho a la apertura del proceso, entendiendo esto como el derecho a ser parte en uno, promoviendo la actividad jurisdiccional en todos sus grados o etapas, permitiendo de esta manera que el justiciable acceda al órgano jurisdiccional para que este resuelva la pretensión. Pero el acceso a la justicia no solo consiste en lo que acabamos de afirmar, sino que, además, en que la ley no establezca óbices excesivos o irrazonables que imposibiliten el acceso al proceso, ya sea en una etapa inicial o en etapas recursivas. Por ello el artículo $19 \mathrm{~N}^{\circ} 3$ inciso $6^{\circ}$ de la Constitución Política de la República expresa que "Toda sentencia de un órgano que ejerza jurisdicción debe fundarse en un proceso previo legalmente tramitado. Corresponderá al legislador establecer siempre las garantías de un procedimiento y una investigación racionales y justos"61.

Los obstáculos que pueden conculcar el derecho a un debido proceso pueden estar establecidos como causas o requisitos de admisibilidad de un determinado acto procesal, ya sea en la etapa de discusión, prueba o incluso luego del pronunciamiento de la sentencia, en la fase recursiva o de impugnación.

La situación anterior es especialmente preocupante cuando se establecen requisitos de admisión a un acto procesal iniciador del proceso, pues, la imprecisión en el tenor literal de la norma o un exceso de requisitos de carácter formal o de fondo puede afectar flagrantemente el derecho de acceso a la jurisdicción ${ }^{62}$.

Por estas razones, el legislador debe ser cuidadoso al momento de regular los requisitos de admisión de los actos procesales, pudiendo imponer ciertos obstáculos para el acceso al proceso o para la admisión de los recursos, siempre que dichos óbices estén enderezados a proteger otros derechos, bienes o intereses constitucionalmente protegidos y que guarden proporción con la finalidad perseguida ${ }^{63}$.

En este sentido, los derechos de acceso a la justicia y al recurso excluyen interpretaciones formalistas o ritualistas de normas que establezcan requisitos

\footnotetext{
${ }^{60}$ Sobre este tema Bordalí (2011), pp. 311 y ss.

${ }^{61}$ Cabe recordar que el debido proceso legal también está reconocido por diversos tratados internacionales, a saber, los artículos 10 de la Declaración Universal de los Derechos Humanos, 14.1 del Pacto Internacional de Derechos Civiles y Políticos y 8.1 de la Convención Americana sobre Derechos Humanos.

${ }^{62}$ Esta situación es realmente preocupante y la manifestó OrTeLls (2009), p. 55, al expresar sus críticas sobre los requisitos de admisibilidad que disponía el Anteproyecto de Reforma del Código de Procedimiento Civil chileno de 2006. En este mismo sentido se pronuncia Palomo (2009), p. 105.

${ }^{63}$ PICÓ (1997), p. 45.
} 
de admisibilidad, en cuanto puede afectar el contenido esencial de los derechos que se reclaman, debiendo el Juez hacer una interpretación razonable y razonada, amplia y no restrictiva, no arbitraria de tales normas ${ }^{64}$.

El Tribunal Constitucional, en diversas sentencias, ha afirmado que el artículo 19 № 3 de la Constitución comprende el derecho a la tutela judicial efectiva, que significa que toda persona tienen el derecho a ser juzgada, a presentarse ante el juez, a ocurrir al juez, sin estorbos, gabelas o condiciones que lo dificulten, retarden o impidan arbitraria o ilegítimamente ${ }^{65}$. El mismo Tribunal ha expresado que "la única forma de garantizar la tutela judicial efectiva es a través del acceso efectivo a la jurisdicción en todos los momentos de su ejercicio, que se manifiesta en la exigibilidad de la apertura y consecuencialmente, de la sustanciación del proceso, además del derecho a participar en los trámites del mismo en igualdad de condiciones que los demás intervinientes" ${ }^{\prime 66}$.

El derecho al recurso es un elemento que forma parte del debido proceso. Esto lo ha declarado el Tribunal Constitucional en diversas sentencias ${ }^{67}$. En lo que nos interesa, consideramos que el derecho al recurso puede infringirse cuando el órgano jurisdiccional interpreta las normas que establecen causales de inadmisibilidad de un determinado medio de impugnación en el sentido de obstaculizar, impedir o dificultar la interposición del mismo y su posterior admisión ${ }^{68}$. Los requisitos de admisibilidad de los recursos deben ser claros y precisos y deben ser interpretados de manera razonable y atendiendo al fin que en cada caso persiguen. De esta manera, la exigencia legal de plazos para impetrar un medio de impugnación, que se indiquen los fundamentos de hecho y de derecho, que se señalen peticiones concretas, el cumplimiento de trámites previos al proceso como puede ser la reclamación administrativa previa a la interposición de una demanda o de un recurso, la posibilidad de someterse a una vía extraprocesal de solución de controversias; la imposición de una fianza en una medida prejudicial precautoria; constituyen requisitos razonables para salvaguardar los derechos de las partes ${ }^{69}$.

En consecuencia, en aquellos casos en que los requisitos de admisibilidad impuestos por la ley a un determinado acto procesal no sean razonables o sean desproporcionados, injustificados o se interpreten sin tener en cuenta la finalidad

${ }^{64}$ Ruiz-Rico y Carazo (2013), pp. 58-60.

${ }^{65}$ STC 1470. En el mismo sentido STC 1378; STC 1356, STC 1391; STC 815; STC 946; STC 1418, STC, 1046; STC 1535; STC 1061; STC 1332; STC 792.

${ }^{66}$ STC 1535.

${ }^{67}$ STC 478; STC 1448; STC 2133; STC 2657; STC 2082.

${ }^{68}$ MONTERo (2014), p. 433.

${ }^{69}$ PICÓ (1997), pp. 45-48. 
que persigue la norma o que desconozca la finalidad o los bienes jurídicos que pretende proteger, entonces conculcarán la garantía del debido proceso, particularmente el acceso a la justicia y el derecho al recurso, debiendo, cuanto antes, ser eliminados del ordenamiento jurídico o reinterpretados de manera de otorgar al litigante un justo y racional procedimiento.

\section{La inadmisión y la subsanación}

Siguiendo a Andrés Ciurana, "la subsanación puede concebirse como una técnica de eliminación de vicios o defectos de los actos jurídicos. En este sentido, la subsanación se identifica con cualquier actividad reparadora o correctora de las desviaciones jurídicas que está específicamente orientada a la eliminación de una irregularidad"70. En este mismo sentido se pronuncia Serra Domínguez al definir la subsanación como "la posibilidad de que un acto privado de eficacia pueda adquirirla mediante la realización de actos posteriores que se la otorguen" 71 .

La subsanación se presenta, de esta forma, como una actividad orientada a enmendar el acto viciado, es decir, ajustar la irregularidad del acto de acuerdo a la legalidad del mismo, con el propósito de impedir su posterior invalidación ${ }^{72}$.

La subsanación de defectos o irregularidades que adolece un acto procesal de parte o de terceros técnicos ${ }^{73}$, puede constituir un mecanismo idóneo para impedir que el acto procesal irregular sea declarado inadmisible. En efecto, consideramos que la subsanación en los actos procesales que emanan de las partes o terceros técnicos, constituye aquella actividad procesal desplegada por el autor del acto irregular que repara o pone remedio al defecto, con el objeto de impedir la declaración de inadmisibilidad.

\footnotetext{
${ }^{70}$ ANDRÉS (2005), p. 250.

${ }^{71}$ SERRA (1969), p. 466.

72 Nuestra doctrina suele confundir los términos subsanación y convalidación. Al respecto SaLAS (2004), pp. 89-97; Cоlombo (1997), t. II, pp. 474 y ss.. También véanse las explicaciones sobre dichos vocablos en VerGé (1987), p. 64; Gelsi (1981), p. 246; MaUrino (2001), p. 62; Martín (1996), p. 334; Creus (1995), pp. 80-91.

${ }^{73}$ Hay diferentes tipos de subsanación. Al respecto ANDRÉs (2005), p. 258, refiriéndose al contenido y límites del acto subsanador, sostiene que: "los dos tipos de conducta dan lugar a la subsanación del defecto, pero convendría resaltar las diferencias entre ellas: $1^{\circ}$ ) En el primer caso estaríamos ante una subsanación en sentido propio, pues la eliminación o reparación del defecto se produce sin alterar el contenido del acto subsanable. El acto subsanado tendrá el mismo contenido que tenía el acto subsanable.- $2^{\circ}$ ) Sin embargo, en el segundo supuesto deberíamos hablar de una subsanación impropia. En esta subsanación impropia, el acto subsanador incide sobre el contenido del acto defectuoso. Sin alterar su contenido originario lo complementa o amplía, dando como resultado un acto subsanado cuyo contenido difiere del que originariamente tenía el acto subsanable".
} 
La enmienda o corrección del acto defectuoso se aprecia en aquellas hipótesis en que el legislador utiliza el término subsanar. Aunque tal concepto es escasamente utilizado, nuestro Código de Procedimiento Civil alude a él en tan solo tres disposiciones, a saber: la primera, en el artículo 84 inciso final del CPC, disponiendo que el juez no podrá, subsanar las actuaciones viciadas en razón de haberse realizado estas fuera del plazo fatal indicado por la ley; la segunda, en el artículo 308 del mismo Código a propósito de la subsanación de defectos que el demandante deberá enmendar o corregir en virtud de acogerse una excepción dilatoria; y la tercera, en el artículo 317 del CPC en cuanto a que el demandante reconvencional debe subsanar o enmendar los defectos de que adolezca la demanda reconvencional en virtud de acogerse una excepción dilatoria opuesta contra ella.

De esta forma, cabe destacar que la subsanación de los actos irregulares tiene una función preventiva que impide obtener la declaración de nulidad (si se trata de un defecto que adolezca un acto que emane del órgano jurisdiccional o de sus auxiliares), o de inadmisibilidad (si se trata de un defecto que adolezca un acto que emane de las partes o terceros técnicos).

Nuestra legislación procesal civil carece de una regulación general de la técnica subsanadora, pero tal omisión no impide afirmar que este límite está presente en nuestra legislación, según pasaremos a demostrar.

Respecto a la subsanación de los actos de parte, destacan las siguientes hipótesis: la posibilidad de subsanar la inobservancia de ciertos presupuestos procesales y obstáculos de la misma naturaleza a través de las excepciones procesales o dilatorias (art. 303 CPC); la falta de entrega de una copia de los escritos que presentan las partes puede subsanarse acompañando las respectivas copias, dentro del plazo legal (art. 31 incs. $3^{\circ}$ y $4^{\circ} \mathrm{CPC}$, actualmente derogado por la Ley $\mathrm{N}^{\circ}$ 20.886); la indebida constitución del poder o mandato judicial puede ser corregida enmendando el defecto dentro del plazo legal (art. $2^{\circ}$ inc. $4^{\circ}$ Ley $N^{\circ} 18.120$ ); la posibilidad que tienen los demandados de pedir que la demanda sea puesta en conocimiento de otras personas que no concurrieron a entablarla puede subsanarse a través de un incidente, que tenga por objeto noticiar a aquellos sujetos que no figuran como parte activa del juicio (art. 21 inc. $1^{\circ} \mathrm{CPC}$ ).

En cuanto a la subsanación de los actos que emanan del órgano jurisdiccional, destacan la posibilidad que tiene el juez de poder aclarar, rectificar o enmendar resoluciones judiciales bajo los límites que dispone la ley (arts. 182 y 185 CPC); el ejercicio de sus facultades y potestades oficiales puede prevenir la inobservancia de algún presupuesto procesal (art. 84 inc. final CPC); ciertos requisitos de la demanda pueden ser apreciados de oficio y ordenar la subsanación (art. 256 CPC); la enmienda de ciertos defectos o irregularidades cometidas en el pronunciamiento de ciertas resoluciones judiciales pueden 
subsanarse a través de la solicitud de reposición (art. 181 CPC), del recurso de apelación (art. 186 CPC), etc.

La posibilidad de subsanar un acto durante el transcurso del procedimiento va disminuyendo. Por eso, al inicio del proceso la subsanación de defectos debe ser la regla general, porque de esa manera se fomenta el acceso a la justicia. En etapas más avanzadas, la inadmisión responde a otras finalidades que ya hemos mencionado, por ejemplo, ser un instrumento que fomente la economía procesal, un filtro para la interposición de un recurso, una posible respuesta a los abusos de presentaciones de escritos sin cumplir los requisitos que dispone la ley.

Cualquiera sea el estado del proceso, cabe señalar que las causales de inadmisión deben ser adecuadas y proporcionadas, deben responder a una finalidad específica y no simplemente constituir un obstáculo formal que impide al justiciable acceder a la justicia. La interpretación de las normas que establecen requisitos de admisibilidad también debe hacerse sin excesivo rigor formal, exenta de construcciones formalistas que atenten contra el acceso a la justicia, el derecho al recurso y, en definitiva, contra un debido proceso.

\section{La subsanación y la preclusión}

La legislación no se refiere a la posibilidad general de subsanar un acto defectuoso ejecutado por las partes o terceros. El saneamiento de tales actos está permitido en ciertas hipótesis específicas que el legislador regula, como sucede a propósito de las excepciones dilatorias que cabe oponerlas contra la demanda (art. 303 CPC) y contra la demanda reconvencional (art. 317 CPC) y la debida constitución del mandato judicial (art. $2^{\circ}$ inc. $4^{\circ}$ Ley $\mathrm{N}^{\circ} 18.120$ ).

Un defecto en el ejercicio de los poderes o facultades de las partes o terceros puede significar la declaración de inadmisibilidad del acto por haberse ejercido de manera defectuosa. Ahora, el ejercicio defectuoso del acto procesal podría tener como consecuencia que se entienda precluida la posibilidad de ejecutarlo correctamente.

Este tema no ha sido abordado por nuestra doctrina, sí por la comparada, la cual sostiene que "si se trata de un derecho subjetivo o una facultad de las partes o de los terceros, el ejercicio defectuoso declarado judicialmente se equipara a su no ejercicio y, como consecuencia de la equiparación, se hace posible que concurriendo algunas de las causales (...) el derecho o facultad se tengan inmediatamente por precluidos" ${ }^{\prime 74}$. En otras palabras, "... la preclusión, cuando opera, actúa como un impedimento o una imposibilidad: la facultad procesal no usada, o indebida o deficientemente usada, se extingue para la parte, quien

${ }^{74}$ VALLINÉS (2004), p. 132. 
ya en el futuro no podrá usar de ella, ni corregir ni integrar su actividad, si la hubiera usado" ${ }^{\prime 75}$.

En nuestro ordenamiento, tal efecto preclusivo no es desconocido, pues el artículo $2^{\circ}$ inciso $4^{\circ}$ de la Ley $N^{\circ} 18.120$ dispone que "si al tiempo de pronunciarse el tribunal sobre el mandato este no estuviere legalmente constituido, el tribunal se limitará a ordenar la debida constitución de aquél dentro de un plazo máximo de tres días. Extinguido este plazo y sin otro trámite, se tendrá la solicitud por no presentada para todos los efectos legales". Luego, el inciso $5^{\circ}$ del mismo artículo hace extensible esta disposición a otros actos procesales disponiendo que "lo dispuesto en este artículo se aplicará también a la delegación del mandato y a las autorizaciones para diligenciar exhortos. En este último caso, las calidades a que se refiere el inciso primero de este artículo se acreditarán ante el tribunal exhortado".

Similar situación es la contenida en el artículo 317 inciso $2^{\circ}$ del CPC, al disponer que "acogida una excepción dilatoria, el demandante reconvencional deberá subsanar los defectos de que adolezca la reconvención dentro de los diez días siguientes a la fecha de notificación de la resolución que haya acogido la excepción. Si así no lo hiciere, se tendrá por no presentada la reconvención, para todos los efectos legales, por el solo ministerio de la ley".

Idéntica sanción se establece en el artículo 31 inc. $4^{\circ}$ del CPC en la parte que indica que se tendrá "... por no presentado el escrito" en el evento que la parte no cumpla con acompañar las copias de los escritos, dentro del plazo legal.

En el evento que el justiciable no subsane el respectivo vicio dentro de la oportunidad correspondiente, el juez debe aplicar la disposición legal que corresponda, en virtud de la cual, hará efectivo el apercibimiento y tendrá por no presentada la solicitud respectiva para todos los efectos legales, precluyendo o caducando la posibilidad de ejecutarlo posteriormente.

Se trata de una sanción drástica, pues, por ejemplo, en el procedimiento ordinario, en el evento que el demandado haya opuesto excepciones dilatorias, o haya deducido un incidente de nulidad por falta de emplazamiento, o haya opuesto excepciones perentorias, o adopte cualquier actitud activa frente a la demanda, pero haya constituido indebidamente mandato judicial y, constatada esa irregularidad, no subsane el defecto dentro de plazo legal, la consecuencia será que se tendrá por no presentada la solicitud y quedará rebelde generándose todas las consecuencias propias de tal institución ${ }^{76}$.

Algunas sentencias han decretado la preclusión de la facultad por el ejercicio defectuoso del acto procesal. Así, por ejemplo, entre otras, el artículo 361 del

${ }^{75}$ JUÁREZ (1946), p. 356.

${ }^{76}$ CarRasco (2010), pp. 51-81. 
CPC prohíbe examinar testigos que no figuren en la lista que debe presentar cada parte en el plazo fatal de 5 días establecido en el inciso $2^{\circ}$ del mismo artículo, y que dicha lista debe contener nombre, domicilio, profesión, etc., de los testigos, por lo que si dentro del plazo señalado solo se presenta una lista con el nombre de los testigos, esta omisión no podrá subsanarse pasados los 5 días, ya que caduca por el ministerio de la ley el derecho de las partes para ampliar o completar la lista referida ${ }^{77}$.

Otro caso ocurre con la incorrecta interposición de los recursos de casación en la forma y apelación (art. 770 CPC). Algunas sentencias declaran que si en el escrito de interposición de los recursos, en lo principal se deduce el de apelación y en el otrosí el de casación en la forma, no se guarda el orden lógico de interposición, actuando la preclusión respecto del recurso de casación en la forma ${ }^{78}$.

${ }_{77}$ CA. de Santiago, 31 de octubre de 1903, GT., $1^{\circ}$ sem., 1904, secc. civil, sentencia № 410, págs. 520 y ss., $\left(\right.$ considerandos $2^{\circ}$ y $3^{\circ}$ ).

${ }^{78}$ CA. de San Miguel, 28 de octubre de 2009, rol No 445-2009, (Cita Legal Publishing: CL/JUR/4648/2009). La Corte afirmó lo siguiente: “1 ${ }^{\circ}$ ) Que el recurrido, señaló, en estrados que al haberse interpuesto el recurso de casación en el otrosí de la presentación de fojas 63 y en lo principal haberse deducido apelación, precluyó para el demandado su derecho a solicitar la casación del fallo, por lo que solicitó se declare inadmisible el recurso de casación interpuesto. $2^{\circ}$ ) Que el Abogado don (...). representante del demandado, en lo principal de su escrito de fs. 63, apeló de la sentencia de primer grado y solicitó su revocación. Además, en el primer otrosí de dicha presentación interpuso recurso de casación en la forma en contra del aludido fallo, pidiendo que se anule por adolecer de vicios que conducen irrefragablemente a dicha sanción. $3^{\circ}$ ) Que si bien el recurrente ha dado parcial cumplimiento a lo preceptuado por el artículo 770 del Código de Procedimiento Civil, al presentar conjuntamente dichos recursos, en lo sustancial se advierte que no observó el orden que la lógica impone para su interposición, de modo tal que se ha producido la preclusión del recurso de casación en la forma. En efecto, al pedir en lo principal de su presentación derechamente la revocación del fallo de primera instancia, sin que haya hecho alegaciones, en ese apartado, respecto que la sentencia contenga vicios de tal entidad que la transformen en una resolución nula, ha reconocido implícitamente la validez de la misma, luego no corresponde que posteriormente invoque su invalidación, porque tal facultad caducó en virtud de su propio y expreso reconocimiento. $4^{\circ}$ ) Que en las condiciones establecidas, por las razones ya indicadas y siendo el recurso de casación en la forma de derecho estricto, y no habiéndose observado por el recurrente de la acción de nulidad la ritualidad lógica del procedimiento, el aludido recurso no podrá prosperar y deberá ser declarado inadmisible". En similar sentido, CS. 30 de noviembre de 2006, rol № 5912-2004, (Cita Legal Publishing: 35694), (considerando 10) sostuvo "que el artículo 770 del Código de Procedimiento Civil, establece que los recursos deben ser interpuestos conjuntamente, esto es, a un mismo tiempo y no de manera subsidiaria como lo ha hecho el recurrente, lo cual importa un vicio en la manera de proponerlo. En efecto, la razón de texto de tal disposición guarda armonía con la naturaleza de los recursos ya que al suponer vicios que invalidan el fallo, la subsidiariedad no tiene cabida porque significa que el recurrente al deducir el recurso en examen, sólo para el evento que el de fondo no sea aceptado, valida o refrenda los vicios, que luego intenta revivir dado el supuesto que sus alegaciones de fondo no sean aceptadas, lo cual atenta contra el principio genérico de la nulidad procesal. El orden lógico en que se deben interponer ambos recursos de conformidad a lo estatuido en el artículo 770 del Código de Procedimiento Civil, es primero el de forma y en segundo término el 
Otra sentencia expresó, a propósito de la adhesión a la apelación, que el apelante debe expresar las peticiones concretas que formula respecto de la sentencia apelada, siendo improcedente subsanar tal defecto presentando, posteriormente, un escrito en que se formulan las peticiones omitidas, porque la oportunidad legal que el apelado tiene para formular sus peticiones es el adherimiento a la apelación y no después ${ }^{79}$.

Sin embargo, también existen algunas sentencias que sostienen que el ejercicio defectuoso de un acto procesal no genera la preclusión de esa actuación. Así, por ejemplo, una sentencia dispuso que el “... escrito presentado dentro del plazo de cinco días que el artículo 80 inciso $2^{\circ}$ del citado Código, contempla para impetrar la acción rescisoria a que se refiere su inciso primero, así como el hecho de valer dentro de similar término consagrado en el artículo 189 de ese Cuerpo Legal para recurrir de apelación, cuya simple omisión formal consistente en la carencia de firma ha sido subsanada fuera de aquellos plazos, adquiere plena validez y es idóneo para lograr los objetivos que procesalmente se propone, que en la especie no son otros que la formulación oportuna de la incidencia y la apelación referidas, sin que obste a lo anterior la falta de autorización del poder a que ya se ha hecho alusión, toda vez que esta no ha sido sino la necesaria consecuencia de la omisión anotada" ${ }^{\prime 80}$.

de fondo y no a la inversa como se procedió en el presente caso, porque habiendo esta Corte emitido pronunciamiento sobre la cuestión de derecho a ella sometida al resolver el primero de los recursos planteados, está impedida en virtud de haber operado la preclusión de examinar una causal que se funda en un presunto vicio de procedimiento, que pretende nada menos que llevarla a invalidar su propia sentencia. El artículo 808 del Código de Procedimiento Civil, corrobora esta interpretación, al establecer que si contra una sentencia se interponen recursos de casación en la forma y en el fondo, y se acoge el de forma, se tendrá como no interpuesto el de fondo. No regula la situación inversa, lo que deja claro que para el legislador no resulta posible que ella se dé".

${ }^{79}$ CA. de Santiago, 9 de julio de 1945, RDJ., t. XLII, sec. $2^{\text {a }}$, págs. 33 y ss., (considerando $7^{\circ}$ ) expresa: "7. ${ }^{\circ}$ Que es inadmisible la pretensión de la parte demandante de subsanar el vacío anotado mediante el escrito de fojas 249 , en que complementa el de adherimiento de fojas 246 , formulando las peticiones omitidas, no ya sólo en cuanto a las declaraciones tercera y cuarta de la sentencia, a que habría circunscrito primeramente sus agravios, sino que también en cuanto a las restantes, porque la oportunidad legal que tuvo esta parte para formular estas peticiones, como apelado, fue el adherimiento a la apelación y no después, de acuerdo con lo que disponen expresamente los artículos 216 y 218 del Código de Procedimiento Civil, el primero de los cuales prescribe que el adherimiento debe efectuarse 'en la forma y dentro de los plazos que expresan los artículos siguientes', y el segundo, especifica que 'en segunda instancia la adhesión podrá solo efectuarse, cuando se trate de sentencia definitiva -cuyo es el caso de autos- en el escrito de respuesta a la expresión de agravios".

${ }^{80}$ CS. 22 de noviembre de 1982, FM., № 288, sentencia № 5, págs. 516 y ss., (considerando $3^{\circ}$ ). En este mismo sentido, la CA. de Rancagua, 22 de diciembre de 2003, rol № 235, (Cita Legal Publishing: CL/JUR/5615/2003), (considerando $4^{\circ}$ ), afirmó que: “... la fecha de cumplimiento del trámite de que se trate debe entenderse la de entrega del escrito en Secretaría, y no la de la firma del mismo; ello, a condición de que esa firma, si falta, se incluya en un breve plazo que el Tribunal fije...". 
Como se aprecia, queda la duda si nuestro ordenamiento reconoce la posibilidad general de subsanar determinados defectos que padece un acto, pues, en ciertos casos ella se manifiesta procedente y en otros se impide la subsanación en virtud de la preclusión por no haber ejercido esa facultad o poder, o por agotamiento o consumación al haberse ejecutado defectuosamente.

La solución a lo anterior consideramos que debiese constituir una hipótesis de lege ferenda, en la cual se determine la aplicación de una tesis más o menos estricta que haga procedente la subsanabilidad o insubsanabilidad de los defectos de la actividad procesal.

Consideramos que la tendencia más actual es aplicar una tesis menos estricta y, por tanto, dar lugar a la subsanabilidad de los actos procesales irregulares, siempre que esto sea posible. La doctrina más moderna propone que se subsanen los defectos o irregularidades que pueden padecer los actos procesales ${ }^{81}$, fomentándose cada vez más las técnicas subsanadoras, a través de las cuales se manifiesta el principio de conservación de los actos procesales. En razón de esto, nuestra legislación debiese incluir la posibilidad de subsanación general para aquellas hipótesis de ejecución defectuosa de un acto ${ }^{82}$.

La posibilidad de corregir los actos defectuosos se enmarca dentro del derecho de acción en un sentido concreto, es decir, de obtener una sentencia favorable. Lo anterior no debe frustrarse por la ejecución defectuosa de un acto procesal por lo que debería existir la posibilidad de subsanar tal defecto. Además, la posibilidad de subsanación de un acto irregular evita interpretaciones formalistas que son contrarias a la finalidad que se quiere lograr, a través del

${ }^{81}$ En este sentido PICó (1997), p. 50, expresa que “... el artículo 24 de la CE no consagra una regla general y absoluta en favor de la subsanación de los vicios o defectos procesales, sin perjuicio de su tendencia a favorecer la conservación de los actos procesales o la subsanación de los defectos susceptibles de reparación sin ruptura del proceso...". También Pérez-Cruz (2000), t. I, pp. 1510-1511.

${ }^{82}$ La solución puede venir de la experiencia comparada. Así, por ejemplo, el artículo 231 de la LEC 2000 dispone que "el tribunal y el secretario judicial cuidarán de que puedan ser subsanados los defectos en que incurran los actos procesales de las partes, siempre que en dichos actos se hubiese manifestado la voluntad de cumplir los requisitos exigidos por la ley". Sobre este tema, conviene aludir a la explicación que hace De LA OLIVA (2001), p. 433, quien expone que: "sólo se considera subsanable un defecto o vicio en tanto en cuanto el acto, aunque defectuoso, revele la voluntad de cumplimiento del requisito y no ignorancia de su imperatividad, negativa o resistencia a cumplirlo o falta de debida diligencia, de forma que se elimina la 'prima' al litigante descuidado y la fuente de dilaciones que supondrían las negligencias frecuentes". Según explica TAPIA (2011), t. I, pp. 1141-1142, “... adoptando una postura de prudente equilibrio entre el rechazo de cualquier posibilidad de subsanación y la sanación indiscriminada de todos los defectos de que pudieren adolecer los actos procesales, el ordenamiento procesal ofrece unas pautas para establecer el límite de la subsanación de los defectos, poniendo el acento en la función y sentido del acto y su relación con el requisito defectuosamente cumplido; y para aplicar esa regla de proporcionalidad entre la falta cometida (el defecto de forma de que se trate) y la sanción aparejada (ineficacia del acto)". 
cumplimiento del requisito de forma que se infringió, fomentando el acceso a la justicia a través de la enmienda del defecto.

Evidentemente que no estamos de acuerdo con una posibilidad de subsanación a ultranza de todo vicio procesal, porque afectaría el principio de preclusión que informa nuestro procedimiento y los procesos sufrirían una excesiva dilación, la cual se quiere reprimir. No se debiese permitir que el litigante descuidado o poco diligente pudiera enmendar un acto defectuoso, sino que, por el contrario, el ordenamiento jurídico debería contener alguna exigencia que excluya la subsanación del acto ejecutado a sabiendas de ser defectuoso e impedir la dilación maliciosa causada por un litigante inescrupuloso que ejecuta un acto procesal de manera irregular, con el ánimo de dilatar el proceso.

En consecuencia, un justo equilibrio debiera permitir que ciertos actos defectuosos puedan subsanarse y que otros no puedan serlo. Los límites a esta actividad subsanadora debieran estar determinados por el ordenamiento jurídico.

\section{La inadmisión en algunos casos concretos. El excesivo formalismo}

Hemos considerado tratar algunos casos particulares en que los tribunales de justicia han declarado inadmisibles ciertos actos procesales fundado en interpretaciones formalistas ${ }^{83}$. Por la limitación de esta investigación, no nos es posible hacer un examen exhaustivo de todas aquellas hipótesis de inadmisión que debieran reinterpretarse o modificarse. Sin embargo, consideramos que respecto de algunas de ellas conviene hacer ciertas puntualizaciones, a saber:

En el ámbito de las gestiones preparatorias de la vía ejecutiva, en particular la confesión de deuda (arts. 435 y 436 CPC), los tribunales han utilizado la inadmisibilidad in límine para impedir la sustanciación de las mismas, fundado en que la pretensión del actor debe resolverse a través de un juicio declarativo de derechos, debiendo aplicarse un procedimiento declarativo de lato conocimiento y no la gestión preparatoria de la vía ejecutiva de que se trata. A través de esta breve fundamentación, en la actualidad innumerables gestiones preparatorias de la vía ejecutiva de confesión de deuda son indebidamente declaradas inadmisibles ${ }^{84}$. En este sentido, los tribunales superiores de justicia han tenido un

\footnotetext{
${ }^{83} \mathrm{Al}$ respecto aclaramos que el concepto de forma es distinto al de formalismo. En efecto, según expliCa BONET (1981), p. 213: "el formalismo es una profesión intelectual y volitiva en la exquisitez de las formas". Luego agrega que "con un sentido pragmático el formalismo dice: 'primero la forma, después la forma: la forma en todo, nada fuera de la forma'. El aherrojamiento que preconiza este formalismo hace intuir instancias de injusticia, necesidad de conformar la justicia del derecho positivo, dominio de lo aparente frente a lo real".

${ }^{84}$ Es muy común encontrar resoluciones de primera instancia del siguiente tenor: "teniendo presente que la gestión que precede, por su naturaleza debe decir relación con una deuda pura y simple, y no con cuestiones que se deriven del cumplimiento o incumplimiento de obligaciones derivadas de un
} 
rol esencial porque, principalmente las Cortes de Apelaciones, han revocado diversas resoluciones judiciales que inadmiten este tipo de gestiones ${ }^{85}$.

No resulta conveniente que los tribunales inadmitan este tipo de actuaciones fundado simplemente en que entre las partes existe una relación contractual previa, porque es evidente que en la mayoría de los casos en que una persona pide al Juez que cite a la contraria a confesar deuda, existirá un vínculo jurídico previo que dio origen a la deuda cuyo pago se reclama. De esta manera, esta gestión preparatoria de la vía ejecutiva sirve para crear un título ejecutivo, no para que el tribunal declare la existencia de una obligación que no existe o que es incierta ${ }^{86}$.

Otras hipótesis de inadmisión que conviene mencionar por su trascendencia, tienen lugar a propósito de los recursos de casación en el fondo y en la forma.

contrato... no ha lugar a acoger a tramitación la gestión de autos, debiendo ocurrirse por la vía que corresponda" (12 Juzgado Civil de Santiago, rol 2183-2014, confirmada por la Corte de Apelaciones de Santiago el 19 de marzo de 2014 y dejado sin efecto por la Corte Suprema el 15 de octubre de 2014). También los tribunales han dictado este tipo de resolución: "Que conforme al mérito de autos y de los antecedentes y alegaciones que se promueven en esta causa se advierte que la pretensión del actor corresponde a un juicio declarativo de derechos, propio de un procedimiento de lato conocimiento que no puede ser resuelto a través de una gestión como la que se intenta y no dándose los presupuestos fundantes de la acción, que se ha deducido y conforme a lo dispuesto en el artículo 435 del Código de Procedimiento Civil, no ha lugar a someter a conocimiento esta causa bajo el procedimiento que se ha solicitado, sin perjuicio de otros derechos que puedan asistir al compareciente en relación con su pretensión..." (17 Juzgado Civil de Santiago, 9 de marzo de 2016, rol 5272-2014, revocada por la Corte de Apelaciones de Santiago de 26 de julio de 2016).

${ }^{85} \mathrm{~A}$ este respecto son innumerables las sentencias dictadas por Tribunales Superiores de justicia que revocan la inadmisibilidad de la gestión preparatoria de la vía ejecutiva de confesión de deuda. A saber, entre otras, Corte Suprema, 15 de octubre de 2014, rol 21392-2014; Corte de Apelaciones de Santiago, 26 de julio de 2016, rol 7091-2016; Corte de Apelaciones de Santiago, 11 de agosto de 2016, rol 77832016; Corte de Apelaciones de Santiago, 19 de mayo de 2016, rol 4235-2016; Corte de Apelaciones de Santiago, 23 de mayo de 2016, rol 4535-2016; Corte de Apelaciones de Santiago, 11 de agosto de 2016, rol 7257-2016; Corte de Apelaciones de Santiago, 2 de agosto de 2016, rol 7483-2016; Corte de Apelaciones de Santiago, 23 de agosto de 2016, rol 6298-2016; Corte de Apelaciones de Santiago, 23 de junio de 2016, rol 5721-2016; Corte de Apelaciones de Santiago, 4 de julio de 2016, rol 60762016; Corte de Apelaciones de Santiago, 30 de mayo de 2016, rol 4821-2016; Corte de Apelaciones de Santiago, 25 de julio de 2016, rol 7026-2016; Corte de Apelaciones de Santiago, 30 de mayo de 2016, rol 4799-2016; Corte de Apelaciones de Santiago, 16 de junio de 2016, rol 5459-2016; Corte de Apelaciones de Santiago, 21 de marzo de 2016, rol 602-2016; Corte de Apelaciones de Santiago, 22 de septiembre de 2016, rol 9657-2016; Corte de Apelaciones de Santiago, 2 de octubre de 2015, rol 9064-2015; Corte de Apelaciones de La Serena, 25 de mayo de 2016, rol 696-2016; Corte de Apelaciones de Chillán, 5 de junio de 2014, rol 157-2014; Corte de Apelaciones de San Miguel, 1 de julio de 2013, rol 735-2013;

${ }^{86}$ En ciertos casos la gestión preparatoria de la vía ejecutiva, particularmente la confesión de deuda es jurídicamente improcedente como ocurre en aquellas hipótesis en que se pretende cobrar una cantidad de dinero que consistió en una cláusula penal, la cual para ser procedente es necesario que primero se determine el incumplimiento contractual. En este sentido Corte de Apelaciones de San Miguel, 5 de diciembre de 1995, Cita: RDJ2133, MJJ2133 
En efecto, hay una cantidad innumerable de recursos de casación (en la forma y en el fondo) que han sido declarados inadmisibles por diversas irregularidades formales en su interposición. Así por ejemplo, se han declarado inadmisibles recursos de casación en el fondo por no contener un petitorio que indique que la Corte debe dictar sentencia de reemplazo y el contenido de esta ${ }^{87}$; por no haber sido patrocinados por abogado ${ }^{88}$, por haberse indicado en la suma del escrito que el abogado patrocina el recurso, pero no haberse desarrollado el patrocinio en el cuerpo del escrito ${ }^{89}$; por haberse indicado en lenguaje singular que se patrocina el recurso, cuando los recursos interpuestos eran tanto de forma como de fondo ${ }^{90}$; por contener el recurso planteamientos subsidiarios que atentan contra la naturaleza de derecho estricto del mismo ${ }^{91}$. También se han declarado inadmisibles los recursos de casación en la forma y en el fondo que se han interpuesto uno en subsidio del otro y no de forma conjunta ${ }^{92}$.

En general, consideramos que la Corte al declarar inadmisible un recurso de esta naturaleza, fundado en las razones que se han expuesto, interpreta con un evidente rigor formalista las normas jurídicas que regulan ciertos requisitos formales $y$, en otros casos, excede de sus facultades al crear verdaderas causales de inadmisibilidad que no están reconocidas en la ley. Consideramos que esto es preocupante, porque un excesivo rigor formal en la interpretación de una norma como las que regulan este tipo de recursos, constituye la conculcación del acceso a la justicia y el derecho a recurso, más aún si se trata de simples errores o deficiencias meramente formales posibles de subsanar.

Reconocemos también que una especial hipótesis de inadmisibilidad consistente en la falta u omisión de patrocinio en un recurso de casación, dispuesta

\footnotetext{
${ }^{87}$ Corte Suprema, 31 de julio de 2006, rol 1832-2006.

${ }^{88}$ Corte Suprema, 11 de marzo de 1997, rol 183-1996; Corte Suprema, 14 de febrero de 2001, rol 265-2001; Corte Suprema, 9 de marzo de 2006, rol 3278-2005; Corte Suprema 13 de abril de 2004, rol 489-2004; Corte Suprema, 15 de septiembre de 2004, rol 2286-2004; Corte Suprema 20 de octubre de 2004, rol 3181-2004; Corte Suprema, 3 de septiembre de 2007, rol 3675-2007; Corte Suprema 16 de abril de 2001, rol 56-2001.

${ }^{89}$ Corte Suprema, 11 de diciembre de 2006, rol 6257-2006.

${ }^{90}$ Corte Suprema, 22 de abril de 2003, rol 855-2003.

${ }^{91}$ Corte Suprema, 24 de enero de 2006, rol 4521-2005; Corte Suprema, 25 de junio de 2007, rol 1468-2005; Corte Suprema, 26 de marzo de 2007, rol 5698-2006; 23 de noviembre de 2001, rol 2862000; Corte Suprema, 25 de julio de 2007, rol 1468-2005; Corte Suprema, 4 de diciembre de 2002, rol 366-2002; 26 de septiembre de 2001, rol 3506-2001, Corte Suprema, 20 de noviembre de 2001, rol 4285-2001; Corte Suprema, 14 de agosto de 2006, rol 5390-2005.

${ }_{92}$ Corte Suprema, 30 de noviembre de 2006, rol 5912-2004; Corte Suprema, 20 de junio de 2007, rol 3130-2006; Corte de Apelaciones de Santiago, 13 de marzo de 2009, rol 3587-2008; Corte de Apelaciones de Santiago, 8 de septiembre de 2009, rol 5052-2008.
} 
en el inciso final del artículo 772 del Código de Procedimiento Civil ha sido reinterpretada en el sentido que dicha exigencia se entiende cumplida, si el abogado que patrocinó la causa es quien interpuso el recurso de casación ${ }^{93}$. Creemos que esta reinterpretación es la correcta.

Cabe hacer presente que el excesivo rigor formal también se ha manifestado en el ámbito del proceso penal ${ }^{94}$ y laboral, a propósito del recurso de nulidad y el de unificación de jurisprudencia, respectivamente.

En cuanto al recurso de nulidad en materia penal, este se ha declarado inadmisible, entre otros casos, por no haberse expresado con claridad que se invalide la sentencia y el juicio oral o solo este último; o que habiéndose solicitado la nulidad del juicio oral y la sentencia, solo debió solicitarse la nulidad de la sentencia y que se dicte sentencia de reemplazo, por no indicar el contenido de la sentencia de reemplazo, que se realicen peticiones genéricas o alternativas; si se omite señalar que las causales de nulidad se impetran de forma conjunta o subsidiaria; la no agregación material de copias de sentencias, etc. ${ }^{95}$.

En cuanto al recurso de unificación de jurisprudencia en materia laboral, el excesivo rigor formal con que se han interpretado las disposiciones que lo regulan ha impedido que la Corte conozca del recurso interpuesto por haberse declarado inadmisible ${ }^{96}$.

\section{Conclusiones}

1. La inadmisibilidad constituye una sanción de invalidez que consiste en un juicio de calificación de regularidad o validez inicial de los actos que tienen su origen en las partes o terceros técnicos que, en caso de actuar, obstará a que se generen los efectos propios del acto.

\footnotetext{
${ }^{93}$ Corte Suprema, 7 de mayo de 2002, rol 891-2002. En este caso se admitió a tramitación el recurso de casación porque se entendió que el abogado que patrocinaba la causa fue quien presentó el recurso de casación, por lo que el requisito se entiende cumplido. En el mismo sentido Corte Suprema, 18 de abril de 2016, rol 3769-2016; Corte Suprema, 29 de diciembre de 2008, rol 3622-2008; Corte Suprema, 28 de noviembre de 2011, rol 7888-2011; Corte Suprema, 20 de octubre de 2011, rol 69402011; Corte Suprema, 12 de agosto de 2010, rol 4072-2010; Corte de Apelaciones de Rancagua, 1 de julio de 2004, rol 21162.

${ }^{94}$ Estos problemas son denunciados por la doctrina, a saber, puede consultarse, entre otros, la obra completa de Horvitz (2015); Cortez (2004), pp. 105-139; Del Río (2014).

${ }^{95}$ Entre otras, Corte Suprema, 24 de junio de 2014, rol 11651-2014; Corte Suprema, 29 de marzo de 2005, rol 636-2005, Corte Suprema, 25 de marzo de 2004, rol 1296-2004; Corte Suprema, 22 de julio de 2010, rol 3750-2010; Corte Suprema, 12 de octubre de 2004, rol 5065-2004; Corte Suprema, 17 de mayo de 2005, rol 1588-2005; Corte de Apelaciones de Concepción, 20 de noviembre de 2009, rol 507-2009.

${ }^{96}$ Sobre este tema Palomo (2011) pp. 399-415.
} 
2. La inadmisibilidad es predicable respecto de todos los actos de postulación y de causación que emanen de las partes y de terceros en sentido técnico.

3. La calificación de admisibilidad-inadmisibilidad se realiza antes que el acto de parte o de terceros técnicos produzca efectos en el proceso y su declaración de inadmisibilidad impide que el acto procesal produzca sus efectos.

4. Los defectos que motivan la inadmisión de un acto pueden ser subsanables e insubsanables y depende de los fines que la ley asigna a dicha institución en los diversos momentos del proceso.

5. La inadmisión no solo se refiere a un juicio o calificación de cumplimiento de los requisitos de naturaleza procesal o formal de un acto de parte o de terceros técnicos, sino que ha evolucionado en cuanto a que existen hipótesis que permiten declarar inadmisible un acto atendiendo a un juicio o examen sobre el fondo del asunto.

6. Los derechos de acceso a la justicia y al recurso excluyen interpretaciones formalistas o ritualistas de normas que establezcan requisitos de admisibilidad en cuanto puede afectar el contenido esencial de los derechos que se reclaman, debiendo el Juez hacer una interpretación razonable y razonada, amplia y no restrictiva, no arbitraria de tales normas.

7. La inadmisibilidad se diferencia de la nulidad procesal en cuanto al objeto sobre que recae, al momento en que se produce el juicio o calificación de irregularidad y en cuanto a los efectos que genera la aplicación de ambas sanciones.

8. Las causales de inadmisibilidad y su tratamiento procesal, en cuanto exista la posibilidad de volver a proponer correctamente el acto inadmitido, dependen de la finalidad o función que el ordenamiento jurídico asigne a esta sanción.

9. La subsanación de defectos o irregularidades que adolece un acto procesal de parte o de terceros técnicos puede constituir un mecanismo idóneo para impedir que el acto procesal irregular sea declarado inadmisible. Sin embargo, queda la duda si nuestro ordenamiento reconoce la posibilidad general de subsanar determinados defectos que padece un acto, pues, en ciertos casos ella se manifiesta procedente y en otros se impide la subsanación en virtud de la preclusión por no haber ejercido esa facultad o poder, o por agotamiento o consumación al haberse ejecutado defectuosamente. La solución a lo anterior consideramos que debiese constituir una hipótesis de lege ferenda, en la cual se determine la aplicación de una tesis más o menos estricta que haga procedente la subsanabilidad o insubsanabilidad de los defectos de la actividad procesal.

10. En una fase inicial del proceso, la demanda podrá inadmitirse cuando falten aquellos presupuestos procesales indispensables para la validez del juicio. Así ocurrirá, por ejemplo, cuando no se cumplan los requisitos formales de la misma, debiendo el tribunal de que se trate dar la posibilidad de corregir el vicio o defecto de que adolece. Lo mismo ocurrirá con las exigencias de 
ius postulandi, particularmente con la necesidad que la parte comparezca por medio de un mandatario judicial. Solo excepcionalmente se podrá inadmitir una demanda por razones de fondo -siempre que la ley establezca esta causal particular de inadmisibilidad-, cuando la pretensión que se impetra sea inaccionable, es decir, que el ordenamiento jurídico no proteja el interés alegado o no pueda ser propuesta porque el ordenamiento jurídico no puede amparar tal situación, como por ejemplo ocurre en el procedimiento de familia, a propósito del artículo 54-1, inciso $3^{\circ}$, de la Ley $N^{\circ} 19.968$ o con la causal de inadmisibilidad establecida a propósito de la acción de protección, por no señalar hechos que puedan afectar garantías constitucionales.

11. En etapas más avanzadas del proceso, particularmente en fase recursiva, los requisitos de admisibilidad de los recursos deben ser interpretados sin un excesivo rigor formal pues, de lo contrario, se afectará el derecho al recurso y, además, los tribunales deben atenerse a revisar solo las causales que la ley expresa, estando impedidos de crear causales de inadmisibilidad que el ordenamiento jurídico no establece.

\section{BiBLIOGRAFÍA CITADA}

AguirReZÁbal Grünstein, Maite (2014): Defensa de los consumidores y acceso a la justicia. Un análisis del procedimiento colectivo en la legislación chilena, La Ley/Legalpublishing/Thomson Reuters, Santiago.

Aguirrezábal Grünstein, Maite (2013a): "Artículo 50" en De la Maza Gazmuri, Pizarro Wilson y Barrientos Camus (directores y coordinadora respectivamente), La protección de los Derechos de los Consumidores. Comentarios a la ley de protección a los derechos de los consumidores, Fundación Fernando Fueyo / Legal Publishing / Thomson Reuters, pp. 967-976

Aguirrezábal Grünstein, Maite (2013b): "Artículo 52" en De la Maza Gazmuri, Pizarro Wilson y Barrientos Camus (directores y coordinadora respectivamente), La protección de los Derechos de los Consumidores. Comentarios a la ley de protección a los derechos de los consumidores, Fundación Fernando Fueyo / Legal Publishing / Thomson Reuters, pp. 1027-1033.

Alsina, Hugo (1963): Tratado teórico práctico de derecho procesal civil y comercial, edit. Ediar, Buenos Aires.

Andrés Ciurana, Baldomero (2005): La invalidez de las actuaciones en el proceso civil, edit. Tirant lo Blanch, Valencia.

Arellano García, Carlos (2005): Teoría general del proceso, edit. Porrúa, México, $14^{\mathrm{a}}$ edic.

Bedaque, José Roberto dos Santos (2010): Efetividade de processo e técnica processual, edit. Malheiros, Sao Paulo. 
BerIzOnCE, Roberto Omar (1993): "La audiencia preliminar en el Código Procesal Civil modelo para Iberoamérica", en XIII Jornadas Iberoamericana de Derecho Procesal, edit. Instituto de Investigaciones Jurídicas (Universidad Autónoma de México), México, pp. 451-470.

BERIZONCE, Roberto Omar (2007): “Principio pro actione, informalismo y exceso de ritual manifiesto (Doctrinas concordantes de los Tribunales Superiores españoles y argentinos)", en El tribunal Supremo, su doctrina legal y el recurso de casación. Estudios en homenaje al profesor Almagro Nosete, edit. lustel, Madrid, pp. 5-16.

Bonet Navarro, Ángel (1981): "Rasgos de forma y formalismos en el proceso. En defensa de la forma", en Escritos sobre la jurisdicción y su actividad, edit. Talleres editoriales Cometa S.A., Zaragoza, pp. 175-237

Bordalí Salamanca, Andrés (2011): "Análisis crítico de la jurisprudencia del Tribunal Constitucional sobre el derecho a la tutela judicial", en Revista Chilena de Derecho, 2011, vol. 38, № 2, pp. 311-337.

Bordalí Salamanca, Andrés (2010): "Legitimación activa del Estado para demandar la reparación del ambiente dañado y una indemnización de perjuicios (Corte Suprema)", en Revista de derecho (Universidad Austral), vol. XXIII, $N^{o}$ 2, diciembre, pp. 225-235.

Bordalí Salamanca, Andrés (2016): "Nulidad procesal" en Cortez Matcovich, Gonzalo (dir.) Proceso civil: los recursos y otros medios de impugnación, edit. Thomson Reuters / La Ley, Santiago, pp. 389-394

Bruna Contreras, Guillermo (1998): "Los autos acordados de la Corte Suprema sobre recurso de protección", en Revista Chilena de Derecho, № especial, pp. 131-135

Calamandrel, Piero (1973): Derecho procesal civil. Estudios sobre el proceso civil, (traducción de Santiago Sentís Melendo), edit. E.J.E.A., Buenos Aires.

Calamandrel, Piero (1996), Instituciones de derecho procesal civil (traducción de Santiago Sentís Melendo), edit. El Foro, Buenos Aires

Camiruaga Churruca, José Ramón (2004): De las notificaciones, edit. Jurídica de Chile, $4^{a}$ edic., Santiago.

Cañas Sepúlveda, Francisco (2013): "Declaración de inadmisibilidad frente a un segundo requerimiento en la segunda gestión pendiente. La jurisprudencia del tribunal constitucional", en Revista de Derecho, Universidad Católica del Norte, v. 20, № 1, pp. 61-78.

Carnelutti, Francisco (1973): "Instituciones del proceso civil", (traducción de la $5^{\mathrm{a}}$ edic. italiana por Santiago Sentís Melendo), edit. E.J.E.A., Buenos Aires. 
Carnelutti, Francisco (1944): Sistema de derecho procesal civil (traducción de Niceto Alcalá-Zamora y Castillo y Santiago Sentís Melendo), edit. Uteha, Buenos Aires, 1944.

Carrasco Poblete, Jaime y Garrote Campillay, Emilio (2011), "Legitimación en el proceso constitucional de Inaplicabilidad a partir de la Ley de Reforma Constitucional № 20.050", en Arancibia Mattar, Martínez Estay, Romero Seguel (dir.), Litigación pública, Abeledo Perrot/Thomson Reuters, Santiago, pp. 151-158.

Carrasco Poblete, Jaime (2015): "El régimen de nulidad procesal en el Proyecto de Ley de nuevo Código de Procedimiento Civil", en Romero Rodríguez, Sophía (dir.) Reforma Procesal Civil y experiencia española, edit. Thomson Reuters / La Ley / Legal Publishing, pp. 5-67.

CARRASCo Poblete, Jaime (2010): La rebeldía en los procesos civil y laboral, edit. Abeledo Perrot/Legal-Publishing, Santiago.

Chiovenda, Giuseppe (1954): "Instituciones de derecho procesal civil" (traducción del italiano por Emilio Gómez Orbaneja), edit. Revista de Derecho Privado, Madrid.

CierCo SeIRA, César (2009): La inadmisión en el procedimiento administrativo, edit. lustel, Madrid.

Clariá Olmedo, Jorge (1983): Derecho procesal. Estructura del proceso, edit. Depalma, Buenos Aires.

Colombo Campbell, Juan (1997): Los actos procesales, Editorial Jurídica de Chile, Santiago, 1997.

Cortez Matcovich, Gonzalo (2013): "Artículo 50" en De la Maza Gazmuri, Pizarro Wilson y Barrientos Camus (directores y coordinadora respectivamente), La protección de los Derechos de los Consumidores. Comentarios a la ley de protección a los derechos de los consumidores, Fundación Fernando Fueyo / Legal Publishing / Thomson Reuters, pp. 951-966

Cortez Matcovich, Gonzalo (2004): "El excesivo rigor formal y otras limitaciones impuestas al recurso de nulidad", en Revista de Derecho, Universidad de Concepción, № 215, pp. 105-139.

COUTURE, Eduardo (2011): Fundamentos del derecho procesal civil, edit. B y F, $4^{\mathrm{a}}$ edic., Buenos Aires.

Couture, Eduardo (2013): Vocabulario jurídico, Editorial Metropolitana / B y F, Buenos Aires, $4^{\mathrm{a}}$ edic.

Creus, Carlos (1995): La invalidez de los actos procesales penales, edit. Astrea, Buenos Aires, $2^{\text {a }}$ edic.

De la Oliva Santos, Andrés (con Díez Picazo, Vegas y Banacloche) (2001): Comentarios a la Ley de Enjuiciamiento Civil, edit. Civitas, Madrid. 
De la Oliva Santos, Andrés, Fernández, Miguel Ángel (1992): Derecho procesal civil, edit. Centro de Estudios Ramón Areces S.A., $3^{\text {a }}$ edic., Madrid.

De LA RúA, Fernando (1991): Teoría general del proceso, edit. Depalma, Buenos Aires.

Del Río Ferretti, Carlos (2014): El derecho al recurso y el recurso de nulidad penal, Legal Publishing, Santiago.

FaIRén GuilléN, Víctor (1955): "La demanda en el proceso civil español", en Estudios de Derecho Procesal, Editorial Revista de Derecho Privado, Madrid, pp. 448 y ss.

FAIRÉn GuILlén, Víctor (1990): Doctrina general del derecho procesal, edit. Bosch, Barcelona.

Fernández, Miguel Ángel (con De la Oliva Santos, Andrés) (1992): Derecho procesal civil, edit. Centro de Estudios Ramón Areces S.A., $3^{\text {a }}$ edic., Madrid.

Ferrada Bórquez, Juan Carlos, Bordalí Salamanca, Andrés, Cazor Aliste, Kamel (2003): "El recurso de protección como mecanismo de control jurisdiccional ordinario de los actos administrativos: una respuesta inapropiada a un problema jurídico complejo", en Revista de Derecho, Universidad Austral (Valdivia-Chile), vol. 14, pp. 67-81.

Ferrada Culaciati, Francisco (2011): La prueba ilícita en el sistema procesal civil, edit. Abeledo Perrot/Legal Publishing Chile, Santiago.

GelSI BIDART, Adolfo (1981): De las nulidades en los actos procesales, Ediciones Jurídicas Amalio M. Fernández, Montevideo.

Gimeno Gámarra, Rafael (1949): "El incidente de nulidad de actuaciones", en Revista de Derecho Procesal, No 1, pp. 511-525.

Gimeno Sendra, Vicente (2007): Introducción al derecho procesal, edit. Colex, Madrid, $3^{\text {a }}$ edic.

Goldschmidt, James (1936a): Derecho procesal civil, (traducción de la 2a edic. alemana por Leonardo Prieto Castro), edit. Labor, Madrid.

GolDSCHMiDT, James, (1936b): Teoría general del proceso (traducción de Leonardo Prieto Castro), edit. Labor, Madrid.

Gorıgortía Aввоtt, Felipe (2013): "Irregularidad, invalidez e ineficacia en el contexto de la nulidad procesal", en Revista de Derecho, Universidad Católica del Norte, № 20, t. I, pp. 129-154.

Guasp, Jaime, Aragoneses, Pedro (2002): Derecho procesal civil, edit. Civitas, $5^{a}$ edic., Madrid.

HeRnÁndez Basualto, Héctor (2002): “La exclusión de la prueba ilícita en el nuevo proceso penal chileno, Colección de investigaciones jurídicas", Universidad Alberto Hurtado, Escuela de Derecho, Santiago, № 2. 
Hernández GalileA, Jesús Miguel (1995): La nueva regulación de la nulidad procesal, edit. Forum, Oviedo.

Horvitz Lennon, María Inés (2015): El recurso de nulidad en materia penal. Jurisprudencia de la Corte Suprema 2001-2013, Editorial Jurídica de Chile.

Hunter Ampuero, Iván (2009), "El poder del juez para rechazar in limine la demanda por manifiesta falta de fundamento, en Revista lus et Praxis, v. 15, $\mathrm{N}^{\circ} 2$, pp. 117-163.

JARA CASTRO, Eduardo (2014): Derecho procesal de familia, Editorial Jurídica de Chile, Santiago.

JuÁrez Echegaray, Luis (1946): "La preclusión", en Estudios de derecho procesal en honor de Hugo Alsina, edit. Ediar, Buenos Aires, pp. 355-368.

LIBEDINSKY TSCHORNE, Marcos (2011): "La manifiesta falta de fundamento en el recurso de casación en el fondo", en Verdugo Maríncovich, Mario (dir), Doctrinas esenciales. Gaceta Jurídica. Derecho Procesal, Abeledo Perrot, Santiago, 2011, t. II, pp. 991-998.

LieBMAN, Enrico (1980): Manual de derecho procesal civil (traducción del italiano por Santiago Sentís Melendo), edit. E.J.E.A., Buenos Aires.

López SIMÓ, Francisco (1991): La jurisdicción por razón de la materia, edit. Trivium, Madrid.

MAIER, Julio (1980): Función normativa de la nulidad, edit. Depalma, Buenos Aires. Marinoni, Luiz Guilherme, Pérez Ragone, Álvaro, Núñez OjedA, Raúl (2010): Fundamentos del proceso civil. Hacia una teoría de la adjudicación, edit. Abeledo Perrot/Legal Publishing, Santiago.

Martín de LA LeONa EspinOSA, José María (1996): La nulidad de las actuaciones en el proceso civil, edit. Colex, $2^{\text {a }}$ edic., Madrid.

Massmann Bozzolo, Nicolás (2009): "La admisibilidad del recurso de inaplicabilidad: a tres años de la reforma", en Revista lus et Praxis, v. 15 n. 1, pp. 263-293.

Maturana Miquel, Cristián (2015): Los recursos del Código de Procedimiento Civil en la doctrina y la jurisprudencia, Thomson Reuters / La Ley, Santiago.

MAurINO, Luis Alberto (2001), Nulidades procesales, edit. Astrea, $2^{\mathrm{a}}$ edic., Buenos Aires.

Michel, Gian Antonio (1970): Curso de derecho procesal civil, (traducción de Santiago Sentís Melendo), edit. E.J.E.A., Buenos Aires.

Minı Massoni, Mario (2005): La prueba ilícita en el proceso penal, edit. Metropolitana, Santiago.

Molina de Caminal, María Rosa (2007): Nulidades en el proceso civil, edit. Advocatus, Córdova. 
Montero Aroca, Juan (con Gomez Colomer, Juan Luis, Barona Vilar, Silvia, Calderón Cuadrado, María Pía) (2014), Derecho Jurisdiccional II. Proceso Civil, Tirant lo Blanch, Valencia, $22^{\text {a }}$ edic.

Montero Aroca, Juan (2009), La legitimación en el proceso civil, Barcelona, Bosch.

Mosquera Ruiz, Mario, Maturana Miquel, Cristián (2013): Los recursos procesales. Editorial Jurídica de Chile, Santiago, $2^{a}$ edic., pp. 320 y ss.

Núñez Poblete, Manuel A. (2012): "Los efectos de las sentencias en el proceso de inaplicabilidad en Chile: examen a un quinquenio de la reforma constitucional", en Revista Estudios Constitucionales, año 10, № 1, pp. 15-64.

OBerg YÁÑez, Héctor (2001): “¿Son necesarias las formas procesales?" en Revista de Derecho, Universidad de Concepción, № 209, año LXIX, enero-junio, pp. 199-208.

Ortells Ramos, Manuel (2009): "Sobre el anteproyecto de código procesal civil chileno de 2006. Una 'intervención provocada'", en Carrasco Poblete, Jaime (dir.), Cuaderno de Extensión Jurídica (Universidad de los Andes) № 16, pp. 53-75.

Ortells Ramos, Manuel (2007): Derecho procesal civil, edit. Thomson-Aranzadi, $7^{\mathrm{a}}$ edic., Navarra.

Ortells Ramos, Manuel, et al. (2011), Introducción al derecho procesal, edit. Aranzadi-Thomson Reuters, Pamplona.

Ortells Ramos, Manuel (1999): Introducción al derecho procesal, edit. Comares, Granada.

Otranto, Guido, Morenza, María Eugenia, Ferrarı, Dolores (2005): “Nulidades en el proceso penal", en Nulidades de los actos jurídicos (Carlos Ghersi, director), edit. Universidad, Buenos Aires, pp. 421-448.

Palacio, Lino Enrique (1972): Derecho procesal civil, edit. Abeledo Perrot, Buenos Aires.

PalACIO, Lino Enrique (1991): Manual de derecho procesal civil, edit. AbeledoPerrot, $9^{a}$ edic., Buenos Aires.

Pallares, Eduardo (1991): Diccionario de derecho procesal civil, edit Porrúa, México, $20^{\mathrm{a}}$ edic.

Palomo Vélez, Diego (2016): "El recurso de casación en el fondo", en Cortez Matcovich, Gonzalo (dir.) Proceso civil: Ios recursos y otros medios de impugnación, edit. Thomson Reuters / La Ley, Santiago.

Palomo Velez, Diego (2009): "La apuesta por el modelo de la oralidad en el anteproyecto de Código Procesal Civil", en Carrasco Poblete, Jaime (dir.), Cuaderno de Extensión Jurídica (Universidad de los Andes) № 16, pp. 101-118. 
Palomo Vélez, Diego (2010): "La audiencia previa y el modelo procesal civil oral: consideraciones en torno a una pieza procesal clave", en Reforma procesal civil. Oralidad y poderes del juez, edit. Abeledo Perrot/Legal Publishing, Santiago.

Palomo Vélez, Diego (2008): La oralidad en el proceso civil. El nuevo modelo español, edit. Librotecnia, Santiago.

Palomo Vélez, Diego, Valenzuela Villalobos, Williams (2011): “Declaraciones de inadmisibilidad del recurso de nulidad laboral como restricción indebida al derecho al recurso: jurisprudencia correctiva de la E. Corte Suprema", en Revista de Derecho, Universidad Católica del Norte, v. 18, № 2, pp. 399-415.

Pérez-Cruz Martín, Agustín Jesús (2000): "Artículo 231", en Lorca Navarrete, Antonio María (director), Comentarios a la nueva Ley de Enjuiciamiento Civil, edit. Lex Nova, Valladolid, $2^{\text {a }}$ edic., t. I, pp. 1510-1511.

Pıcó I Junor, Joan (1997): Las garantías constitucionales del proceso, edit. José María Bosch, Barcelona.

Pinochet CANTwell, Francisco José (2013): El recurso de protección, Editorial de Derecho / Editorial El Jurista, Santiago.

Pottstock Padilla, Edmundo (1997): Proceso civil y proceso penal, edit. ConoSur, Santiago.

Prieto-CAstro y Ferrándiz, Leonardo (1982): Tratado de derecho procesal civil, edit. Aranzadi, Pamplona.

Quezada MelénDeZ, José (1984): Derecho procesal civil chileno. De la representación en los actos procesales, edit. Ediar Editores Ltda., Santiago, 2a edic.

Romero Seguel, Alejandro (2017): Curso de derecho procesal civil. De los actos procesales y sus efectos, Thomson Reuters, Santiago.

Romero Seguel, Alejandro (2001): "El control de oficio de los presupuestos procesales y la cosa juzgada aparente. La capacidad procesal", en Revista Chilena de Derecho, vol. 28, № 4, pp. 781-789.

Romero Seguel, Alejandro, Aguirrezábal Grünstein, Maite, Baraona González, Jorge (2008): "Revisión crítica de la causal fundante del recurso de casación en el fondo en materia civil", en Revista lus et Praxis (Universidad de Talca), año 14, № 1, pp. 230-254.

Romero Seguel, Alejandro (2007): Curso de derecho procesal civil. La acción y la protección de los derechos, Editorial Jurídica de Chile, Santiago.

Rubio de Orellana Pizarro, Rosario (1996): "La nulidad de actuaciones en el proceso civil”, en, Díez-Picazo Giménez y Martínez-Simancas y Sánchez 
(director), Estudios sobre derecho procesal, edit. Central Hispano, Madrid, vol. I, pp. 185-228.

Ruiz-Rico Ruiz, Gerardo, Carazo Liébana, María José (2013): El derecho a la tutela judicial efectiva. Análisis jurisprudencial, Tirant lo Blanch, Valencia.

Saenger Gianonı, Fernando (1998) "La lenta agonía del recurso de protección", en Revista Chilena de Derecho, № especial, pp. 259-271.

Salas Vivaldi, Julio (2004): Los incidentes y en especial el de nulidad en el proceso civil, penal y laboral, Editorial Jurídica de Chile, Santiago, $7^{\text {a }}$ edic.

SATTA, Salvatore (1971): Derecho procesal civil, (traducción de Santiago Sentís Melendo y Fernando de la Rúa), edit. E.J.E.A., Buenos Aires.

Serra Domínguez, Manuel (1969): Estudios de derecho procesal, edit. Ediciones Ariel, Barcelona, 1969.

Sото KıOss, Eduardo (1998): "Control jurisdiccional. El derecho fundamental de acceso a la justicia (A propósito de requisitos de admisibilidad)", en Revista Chilena de Derecho, No especial, pp. 273-278.

Sото KıOss, Eduardo (2009): "Control jurisdiccional. El derecho fundamental de acceso a la justicia (A propósito de requisitos de admisibilidad)", en Derecho Administrativo. Temas fundamentales, edit. Legal Publishing/Abeledo Perrot, Santiago, pp. 511-522.

Stoehrel Maes, Carlos Alberto (2009): De las disposiciones comunes a todo procedimiento y de los incidentes. Actualizada por Davor Harasic Yaksic, Editorial Jurídica de Chile, $6^{a}$ edic., Santiago.

TAPIA FernándeZ, Isabel (2011): "Artículo 231. Subsanación" en Comentarios a la Ley de Enjuiciamiento Civil (Cordón Moreno, Faustino, Armenta Deu, Teresa, Muerza Esparza, Julio, Tapia Fernández, Isabel, coordinadores), edit. Aranzadi/Thomson Reuters, Navarra, $2^{\text {a }}$ edic., t. I, pp. 1138-1142.

Tavolari Oliveros, Raúl (1996): Recurso de casación y queja, Editorial Jurídica Conosur, Santiago.

Vallinés García, Enrique (2004): La preclusión en el proceso a civil, edit. Thomson-Civitas, Madrid.

Vergé Grau, Joan (1987): La nulidad de actuaciones, edit. Librería Bosch, Barcelona.

VON Bülow, Oskar (2008): La teoría de las excepciones procesales y de los presupuestos procesales, (traducción de Miguel Ángel Rosas Lichteschein), edit. Ara, Lima.

YélAmOS BAYARRí, Estela (2006): Nulidad procesal y comunicaciones judiciales fallidas, edit. Atelier, Barcelona. 


\section{JURISPRUDENCIA CITADA}

Sentencias del Tribunal Constitucional roles 1470, 1378, 1356, 1391, 815, 946, 1418, 1046, 1535, 1061, 1332; 92, 1535, 478, 1448, 2133, 2657, 2082.

$12^{\circ}$ Juzgado Civil de Santiago, rol 2183-2014.

$17^{\circ}$ Juzgado Civil de Santiago, 9 de marzo de 2016, rol 5272-2014.

CA. de Rancagua, 22 de diciembre de 2003, rol No 235, (Cita Legal Publishing: CL/JUR/5615/2003).

CA. de San Miguel, 28 de octubre de 2009, rol № 445-2009, (Cita Legal Publishing: CL/JUR/4648/2009).

CA. de Santiago, 1 de septiembre de 1998, GJ., 219, 1998, págs. 237-238 (la misma sentencia en Cita Legal Publishing: CL/JUR/1511/1998).

CA. de Santiago, 13 de junio de 1997, RDJ., t. XCIV, sec. 2a , pág. 71.

CA. de Santiago, 17 de enero de 2007, rol No 2925-2006, (Cita Legal Publishing: CL/JUR/6683/2007).

CA. de Santiago, 26 de agosto de 2010, rol No 6788-2009, (Cita Legal Publishing: CL/JUR/12014/2010).

CA. de Santiago, 27 de enero de 1993, RDJ., t. XC, sec. 2a , págs. 14 y ss.

CA. de Santiago, 31 de octubre de 1903, GT., $1^{\text {er }}$ sem., 1904, secc. civil, sentencia $N^{\circ} 410$, págs. 520 y ss.

CA. de Santiago, 9 de julio de 1945, RDJ., t. XLII, sec. 2a a págs. 33 y ss.

CA. de Talca, 9 de agosto de 1991, rol No 44274-1989 (Cita Legal Publishing: CL/JUR/448/1991).

Corte de Apelaciones de Chillán, 5 de junio de 2014, rol 157-2014.

Corte de Apelaciones de Concepción, 2 de septiembre de 2015, rol 364-2015.

Corte de Apelaciones de Concepción, 20 de noviembre de 2009, rol 507-2009.

Corte de Apelaciones de La Serena, 25 de mayo de 2016, rol 696-2016.

Corte de Apelaciones de Rancagua, 1 de julio de 2004, rol 21162.

Corte de Apelaciones de San Miguel, 1 de julio de 2013, rol 735-2013.

Corte de Apelaciones de San Miguel, 5 de diciembre de 1995, Cita: RDJ2133, MJJ2133.

Corte de Apelaciones de Santiago, 11 de agosto de 2016, rol 7257-2016.

Corte de Apelaciones de Santiago, 11 de agosto de 2016, rol 7783-2016.

Corte de Apelaciones de Santiago, 13 de marzo de 2009, rol 3587-2008.

Corte de Apelaciones de Santiago, 16 de junio de 2016, rol 5459-2016.

Corte de Apelaciones de Santiago, 19 de mayo de 2016, rol 4235-2016. 
Corte de Apelaciones de Santiago, 2 de agosto de 2016, rol 7483-2016. Corte de Apelaciones de Santiago, 2 de octubre de 2015, rol 9064-2015. Corte de Apelaciones de Santiago, 21 de marzo de 2016, rol 602-2016. Corte de Apelaciones de Santiago, 22 de septiembre de 2016, rol 9657-2016. Corte de Apelaciones de Santiago, 23 de agosto de 2016, rol 6298-2016. Corte de Apelaciones de Santiago, 23 de junio de 2016, rol 5721-2016. Corte de Apelaciones de Santiago, 23 de mayo de 2016, rol 4535-2016. Corte de Apelaciones de Santiago, 25 de julio de 2016, rol 7026-2016. Corte de Apelaciones de Santiago, 26 de julio de 2016, rol 7091-2016. Corte de Apelaciones de Santiago, 30 de mayo de 2016, rol 4799-2016. Corte de Apelaciones de Santiago, 30 de mayo de 2016, rol 4821-2016. Corte de Apelaciones de Santiago, 4 de julio de 2016, rol 6076-2016.

Corte de Apelaciones de Santiago, 8 de septiembre de 2009, rol 5052-2008.

Corte Suprema 13 de abril de 2004, rol 489-2004.

Corte Suprema 16 de abril de 2001, rol 56-2001.

Corte Suprema 20 de octubre de 2004, rol 3181-2004.

Corte Suprema, 11 de diciembre de 2006, rol 6257-2006.

Corte Suprema, 11 de marzo de 1997, rol 183-1996.

Corte Suprema, 12 de agosto de 2010, rol 4072-2010.

Corte Suprema, 12 de octubre de 2004, rol 5065-2004.

Corte Suprema, 14 de agosto de 2006, rol 5390-2005.

Corte Suprema, 14 de febrero de 2001, rol 265-2001.

Corte Suprema, 15 de octubre de 2014, rol 21392-2014.

Corte Suprema, 15 de septiembre de 2004, rol 2286-2004.

Corte Suprema, 17 de mayo de 2005, rol 1588-2005.

Corte Suprema, 18 de abril de 2016, rol 3769-2016.

Corte Suprema, 20 de junio de 2007, rol 3130-2006.

Corte Suprema, 20 de noviembre de 2001, rol 4285-2001.

Corte Suprema, 20 de octubre de 2011, rol 6940-2011.

Corte Suprema, 22 de abril de 2003, rol 855-2003.

Corte Suprema, 22 de julio de 2010, rol 3750-2010.

Corte Suprema, 23 de noviembre de 2001, rol 286-2000.

Corte Suprema, 24 de enero de 2006, rol 4521-2005.

Corte Suprema, 24 de junio de 2014, rol 11651-2014. 
Corte Suprema, 25 de julio de 2007, rol 1468-2005.

Corte Suprema, 25 de junio de 2007, rol 1468-2005.

Corte Suprema, 25 de marzo de 2004, rol 1296-2004.

Corte Suprema, 26 de marzo de 2007, rol 5698-2006.

Corte Suprema, 26 de septiembre de 2001, rol 3506-2001.

Corte Suprema, 28 de noviembre de 2011, rol 7888-2011.

Corte Suprema, 29 de diciembre de 2008, rol 3622-2008.

Corte Suprema, 29 de marzo de 2005, rol 636-2005.

Corte Suprema, 3 de septiembre de 2007, rol 3675-2007.

Corte Suprema, 30 de noviembre de 2006, rol 5912-2004.

Corte Suprema, 31 de julio de 2006, rol 1832-2006.

Corte Suprema, 4 de diciembre de 2002, rol 366-2002.

Corte Suprema, 7 de mayo de 2002, rol 891-2002.

Corte Suprema, 9 de marzo de 2006, rol 3278-2005.

CS, 25 de octubre de 1963, RDJ, t. LX, sec. 1ª pág. 316.

CS. 1 de octubre de 1925, RDJ., t. XXIII, sec. $1^{\text {a }}$, págs. 477 y ss.

CS. 21 deenero de 2010, rol Nº 6853-2008 (Cita Legal Publishing: CL/JUR/726/2010).

CS. 22 de noviembre de 1982, FM., № 288, sentencia № 5, págs. 516 y ss.

CS. 30 de noviembre de 2006, rol № 5912-2004, (Cita Legal Publishing: 35694).

CS. 9 de enero de 1937, RDJ., t. XXXIV, sec. $1^{\text {a }}$, págs. 184 y ss. 